\title{
Analysis of Shoreline and Geomorphic Change for Breton Island, Louisiana, from 1869 to 2014
}

By Joseph F. Terrano, James G. Flocks, and Kathryn E.L. Smith

Open-File Report 2016-1039

U.S. Department of the Interior

U.S. Geological Survey 


\title{
U.S. Department of the Interior \\ SALLY JEWELL, Secretary
}

\author{
U.S. Geological Survey \\ Suzette M. Kimball, Director
}

U.S. Geological Survey, Reston, Virginia: 2016

For more information on the USGS-the Federal source for science about the Earth, its natural and living resources, natural hazards, and the environment-visit http://www.usgs.gov or call 1-888-ASK-USGS.

For an overview of USGS information products, including maps, imagery, and publications, visit http://www.usgs.gov/pubprod.

Any use of trade, firm, or product names is for descriptive purposes only and does not imply endorsement by the U.S. Government.

Although this information product, for the most part, is in the public domain, it also may contain copyrighted materials as noted in the text. Permission to reproduce copyrighted items must be secured from the copyright owner.

Suggested citation:

Terrano, J.F., Flocks, J.G., and Smith, K.E.L., 2016, Analysis of shoreline and geomorphic change for Breton Island, Louisiana, from 1869 to 2014: U.S. Geological Survey Open-File Report 2016-1039, 34 p., http://dx.doi.org/10.3133/ofr20161039.

ISSN 2331-1258 (online) 


\section{Acknowledgments}

The authors would like to thank Emily Himmelstoss for her assistance in providing light and detection ranging (lidar) uncertainty values for Breton Island; Arnell Forde for reviewing metadata; and Steven Douglas, Kristy Guy, and Karen Morgan for reviewing the report; Betsy Boynton, Ginger Range and Noreen Buster for reviewing and editing the tables and figures; and finally Rebekah Davis with the USGS Science Publishing Network for providing our final review before publication. This project included funding from the Louisiana Outer Coast Early Restoration Project, obtained by the natural resource trustees for the Deepwater Horizon Oil Spill, pursuant to the Framework for Early Restoration Addressing Injuries Resulting from the Deepwater Horizon Oil Spill executed April 20, 2011. 


\section{Contents}

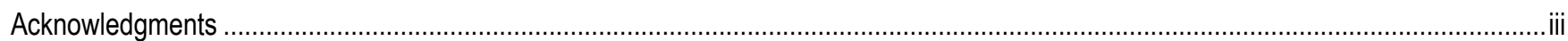

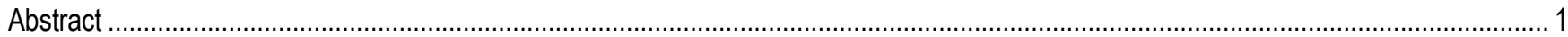

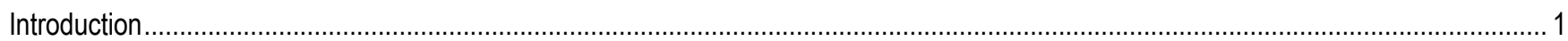

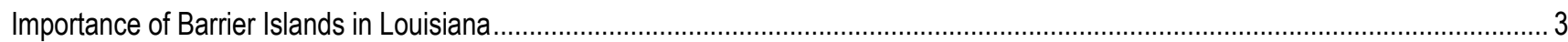

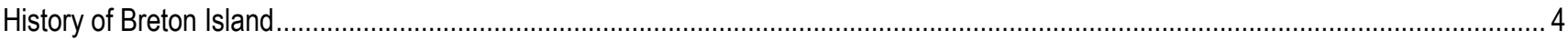

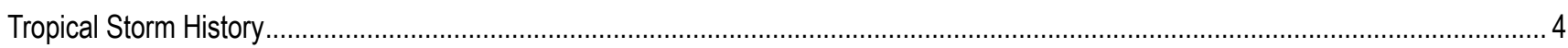

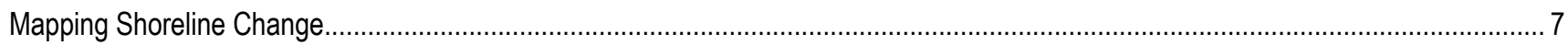

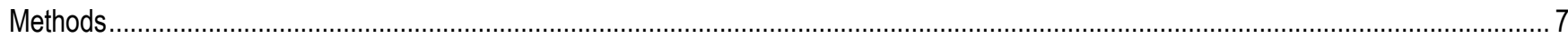

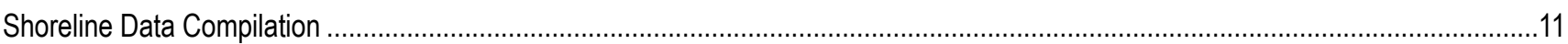

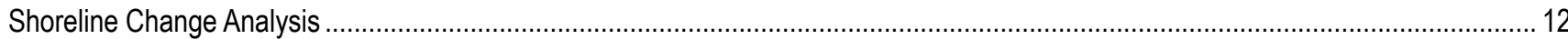

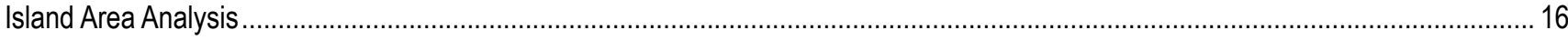

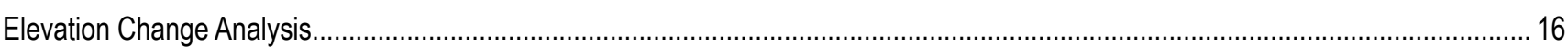

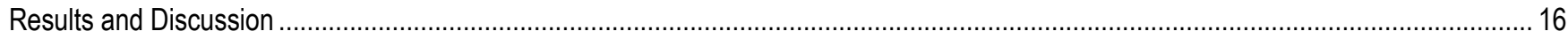

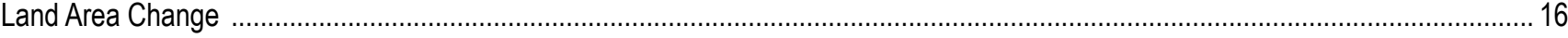

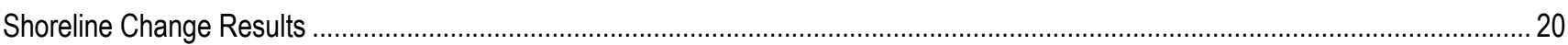

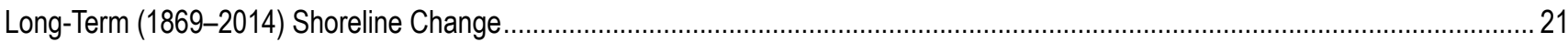

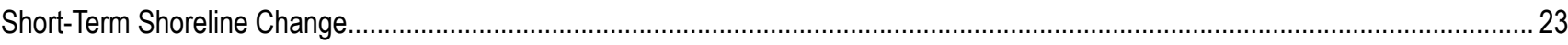

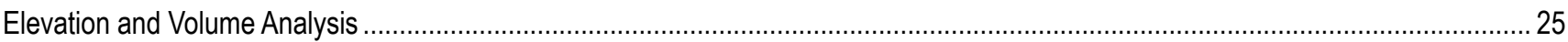

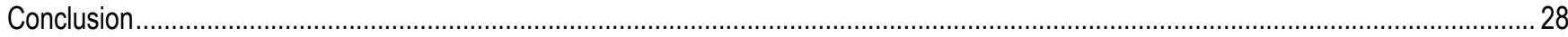

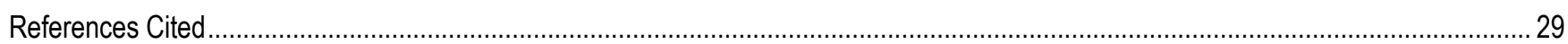




\section{Figures}

1. Location of Breton Island and the southern Chandeleur Islands.

2. Aerial view of Breton Island from the north showing the prevalent sandy shoreline and the limited pelican nesting habitat within the mangroves on the northern part of the island.

3. Tracklines of major hurricanes passing within 150 kilometers and tropical storms passing within 10 kilometers of Breton Island, 1870 to 1949 , and 1950 to 2008

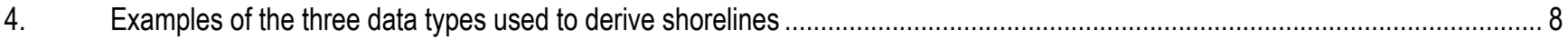

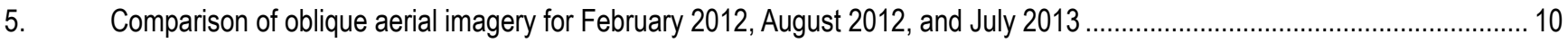

6. Representation of light and detection ranging data of Breton Island, 2013 …........................................................... 12

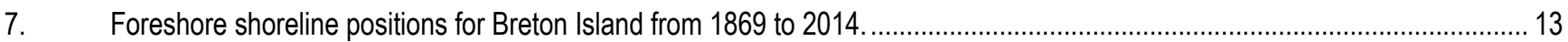

8. All island area polygons mapped to show how the geometry and geographic orientation of Breton Island has changed from

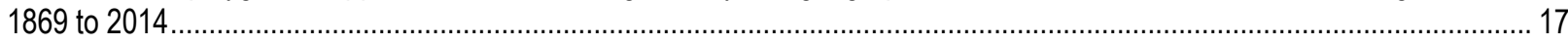

9. Graphs of island area calculated from available shoreline datasets of Breton Island, 1865-2014, and 2001-2014 _................ 18

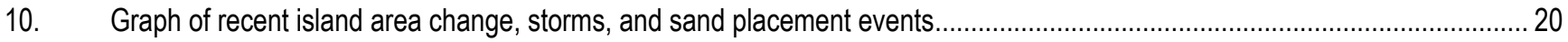

11. Oblique aerial imagery of Breton Island before and after a sand placement event ............................................................. 21

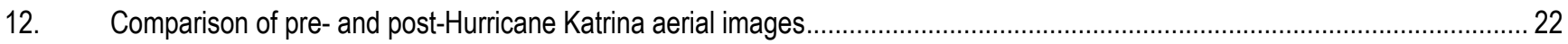

13. Transects before and after clipping to the shoreline change extent for all foreshore shorelines ............................................ 23

14. Map of shoreline change extent clipped transects color-coded by the end point rate for 1869-2014 ................................... 24

15. Maps of light and detection ranging elevation change, between 2007 and 2001, between 2013 and 2007, and between

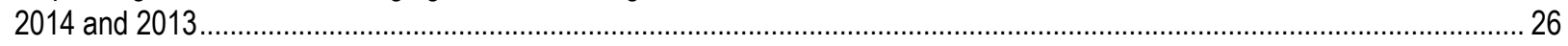

16. Oblique aerial images from August 2012 and July 2013 showing that the southern portion of Breton Island is submerged ....... 27

\section{Tables}

1. Hurricanes passing within 150 kilometers and tropical storms passing within 10 kilometers of Breton Island

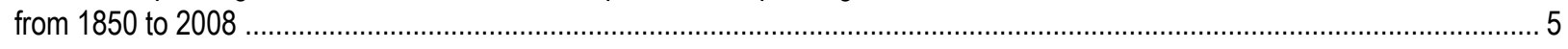

2. Sources of imagery used in the determination of shoreline positions for Breton Island, Louisiana........................................ 9

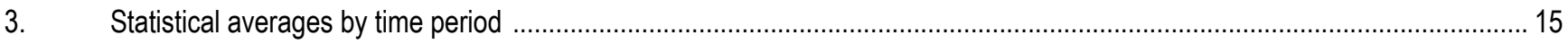

4. Shoreline length and island area for Breton Island ........................................................................................... 19

5. Sediment volume, average elevation, and maximum elevation above the mean high water from light and detection

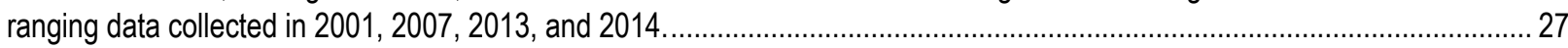




\section{Conversion Factors}

International System of Units to Inch/Pound

\begin{tabular}{ccc}
\hline Multiply & By & To obtain \\
\hline & Length & \\
\hline centimeter $(\mathrm{cm})$ & 0.3937 & inch (in.) \\
meter $(\mathrm{m})$ & 3.281 & foot $(\mathrm{ft})$ \\
kilometer $(\mathrm{km})$ & 0.6214 & mile (mi) \\
kilometer $(\mathrm{km})$ & 0.5400 & mile, nautical (nmi) \\
\hline & Area & acre \\
\hline square kilometer $\left(\mathrm{km}^{2}\right)$ & 247.1 & square mile $\left(\mathrm{mi}^{2}\right)$ \\
\hline square kilometer $\left(\mathrm{km}^{2}\right)$ & 0.3861 & gallon $(\mathrm{gal})$ \\
& Volume & cubic foot $\left(\mathrm{ft}^{3}\right)$ \\
\hline cubic meter $\left(\mathrm{m}^{3}\right)$ & 264.2 & \\
\hline cubic meter $\left(\mathrm{m}^{3}\right)$ & 35.31 & \\
\hline
\end{tabular}

\section{Datum}

Vertical coordinate information is referenced to the North American Vertical Datum of 1988 (NAVD 88), and the units of all vertical measurements are in meters.

Horizontal coordinate information is referenced in the geographic coordinates North American Datum of 1983 (NAD 83); however, data were projected into Universal Transverse Mercator (UTM) coordinate system for analysis purposes.

\section{Supplemental Information}

Data used in this report are available as accompanying data releases. The baseline, transects, and shorelines are available for download from http://dx.doi.org/10.5066/F7XS5SGM. The 2014 light and detection ranging (lidar) data are available for download from http://dx.doi.org/10.5066/F70G3H6G.

Wind speed is given in kilometers per hour $(\mathrm{km} / \mathrm{h})$.

Erosion rate is given in meters per year (m/yr).

Land loss is given in square kilometers per year $\left(\mathrm{km}^{2} / \mathrm{yr}\right)$.

Volume per unit area of islands is given in cubic meters per square kilometers $\left(\mathrm{m}^{3} / \mathrm{km}^{2}\right)$ 


\section{Abbreviations}

$\begin{array}{ll}\text { BICM } & \text { Barrier Island Comprehensive Monitoring } \\ \text { DSAS } & \text { Digital Shoreline Analysis System } \\ \text { EPR } & \text { end point rate } \\ \text { Esri } & \text { Environmental Systems Research Institute } \\ \text { lidar } & \text { light and detection ranging } \\ \text { LRR } & \text { linear regression rate } \\ \text { LR2 } & \text { R-squared of linear regression } \\ \text { MHW } & \text { mean high water } \\ \text { NSM } & \text { net shoreline movement } \\ \text { NOAA } & \text { National Oceanic and Atmospheric Administration } \\ \text { SCE } & \text { shoreline change extent } \\ \text { T-Sheet } & \text { topographic sheet } \\ \text { WLR } & \text { weighted linear regression }\end{array}$




\title{
Analysis of Shoreline and Geomorphic Change for Breton Island, Louisiana, from 1869 to 2014
}

\author{
By Joseph F. Terrano, James G. Flocks, and Kathryn E.L. Smith
}

\begin{abstract}
Many barrier islands in the United States are eroding and losing elevation substantively because of storm surge, waves, and sea-level changes. This is particularly true for the deltaic barrier system in Louisiana. Breton Island is near the mouth of the Mississippi River at the southern end of the Chandeleur barrier island chain in southeast Louisiana. This report expands on previous geomorphic studies of Breton Island by incorporating additional historic and recent datasets. Multiple analyses focus on longand short-term shoreline change, as well as episodic events and anthropogenic modification. Analyses periods include long term (1869-2014), long-term historic (1869-1950), post-Mississippi River-Gulf Outlet (1950-2014), pre/post-Hurricane Katrina (2004-5), and recent (2005-14). In addition to shoreline change, barrier island geomorphology is evaluated using island area, elevation, and sediment volume change. In the long term (1869-2014), Breton Island was affected by landward transgression, island narrowing, and elevation loss. Major storm events exacerbated the long-term trends. In the recent period (2005-14), Breton Island eroded at a slower rate than in the long-term and gained area and total sediment volume. The recent accretion is likely because of the lack of major storms since Hurricane Katrina in 2005.
\end{abstract}

\section{Introduction}

Barrier islands play an important role in protecting mainland shorelines from coastal erosion (Stone and McBride, 1998; Stone and others, 2005) and providing critical habitat for wildlife (Ruple, 1984; Withers, 2002; Curtiss and Pierce, 2015), but are highly dynamic systems susceptible to the natural processes of erosion and accretion (Penland and Boyd, 1981; McBride and Byrnes, 1997; Morton and others, 2004). With time, barrier islands erode and accrete in response to waves, tides, extreme weather events, and anthropogenic influences such as coastal armoring, dredging, and erosional wakes from shipping activity. Hurricanes and storm events in particular play a pivotal role in the development or destruction of a barrier island through storm surge and wave collision, inundation, and overwash (Stone and others, 2004; Stockdon and others, 2007; Sallenger and others 2006; Otovos and Carter, 2008). Barrier islands naturally move in response to erosive processes; and may migrate landward (transgression) from storm overwash and sea-level rise, parallel to the coast from alongshore sediment transport, or both (Penland and others, 1985; Stone and Stapor, 1996, Hoyt 1967). A sediment deficit (when overall erosion is greater than accretion), however, will lead to barrier island submergence and loss of critical habitat. Current and historical shoreline position and area/volume changes often are analyzed in conjunction with storm and other significant events to understand the critical processes dominating island movement, sediment deposition, and erosion. Results of these studies can provide information regarding past development of barrier islands, shoreline and habitat response to storm events and sea-level changes, and predictions of barrier island vulnerability to future events.

This barrier island shoreline and geomorphic analysis focuses on Breton Island, a small barrier island off the coast of Louisiana at the southernmost point of the Chandeleur barrier island chain in the 
north-central Gulf of Mexico (fig. 1). Breton Island provides critical habitat for migratory birds and other wildlife, including waterfowl, sea turtles, and fish. Previous studies have determined that Breton Island is susceptible to erosion and submergence (Williams and others, 1992; Penland and others, 1997; Fearnley and others, 2009, Martinez and others, 2009). The recovery and maintenance of Breton Island is important ecologically for local fauna and mainland marsh protection from waves and storm surge; therefore, continued monitoring of island development in response to anthropogenic effects and natural processes is critical to predicting the effects of future storm events and sea-level changes, planning habitat restoration, protecting endangered species, and developing sediment management plans.

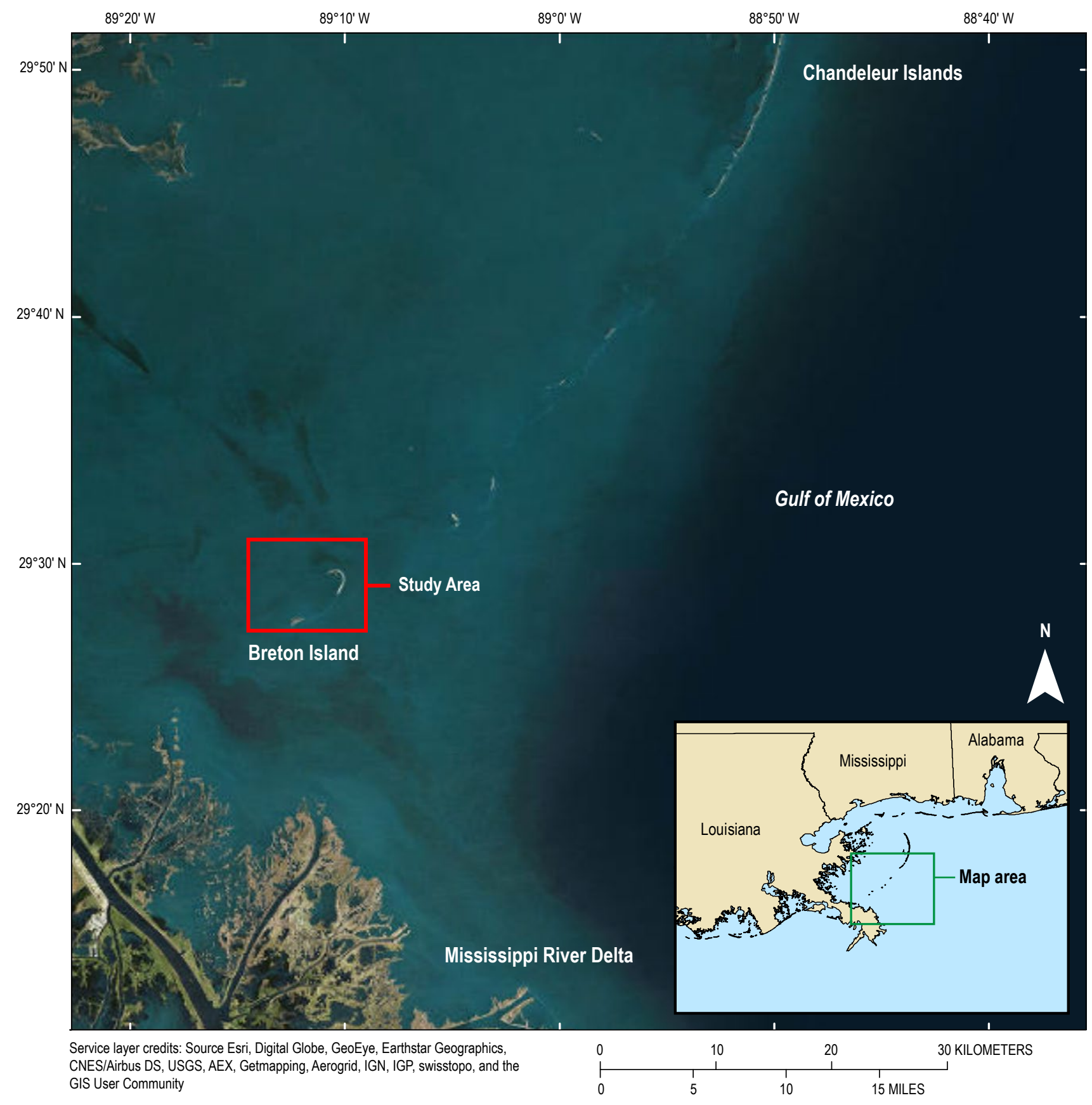

Figure 1. Location of Breton Island and the southern Chandeleur Islands. 


\section{Importance of Barrier Islands in Louisiana}

Breton Island is the southernmost island in a chain of barrier islands designated as the Breton National Wildlife Refuge. The Breton National Wildlife Refuge is recognized as an important refuge primary for migratory and shore birds and is host to one of Louisiana's largest historical brown pelican nesting colonies. Pelicans from the Breton National Wildlife Refuge migrate across the Gulf of Mexico to the U.S. east coast and the Caribbean (U.S. Fish and Wildlife Service, 2015). Following Hurricane Georges (1998), Breton Island bird populations declined because of habitat loss from storm erosion. Populations recovered in the years after the storm, but were decimated again when the Hurricane Katrina storm surge overtopped the island in 2005 (U.S. Fish and Wildlife Service, 2014). Since then, bird populations have been slowly recovering but with reduced available nesting habitat (fig. 2). The pelicans exhibit high site fidelity and continue to return to Breton Island despite decreasingly suitable habitat; therefore, initiatives focused on habitat restoration and sand renourishment efforts could aid in population recovery.

Breton Island provides mainland shoreline protection from waves and storm surges (Stone and McBride, 1998). Nationally, about 40 percent of the coastal and estuarine wetlands within the 48 contiguous United States are found in Louisiana, where wetlands and estuaries provide annual revenues in excess of $\$ 1$ billion in renewable natural resources, such as fisheries (Stone and others, 1997; Williams and others, 1997). Louisiana's barrier islands exhibit a history of island narrowing, landward transgression, and reduction in land area (Kindinger and others, 2013). These effects are largely because of the complex interactions of global sea-level rise, an inadequate supply of sediment, storm overwash, subsidence, natural wave action, and long-term human interactions. The Chandeleur barrier island chain serves as a natural barrier that protects Louisiana's coastal wetlands, bays, and estuaries. If the high rate of barrier island loss continues, the ecosystems they protect will likely decline (Penland and others, 1981; Van Heerden and DeRouen Jr, 1997). Estuaries, beaches, marshes, and other mainland ecosystems all depend on the Louisiana barrier islands to mitigate the wave action and provide protection (Morgan and Larimore, 1957; Stone and McBride, 1998). Although Breton Island is just one island in the barrier island chain, understanding the geomorphic evolution and effect of events on Breton is important in evaluating the future and resilience of the Chandeleur barrier island chain as a whole.

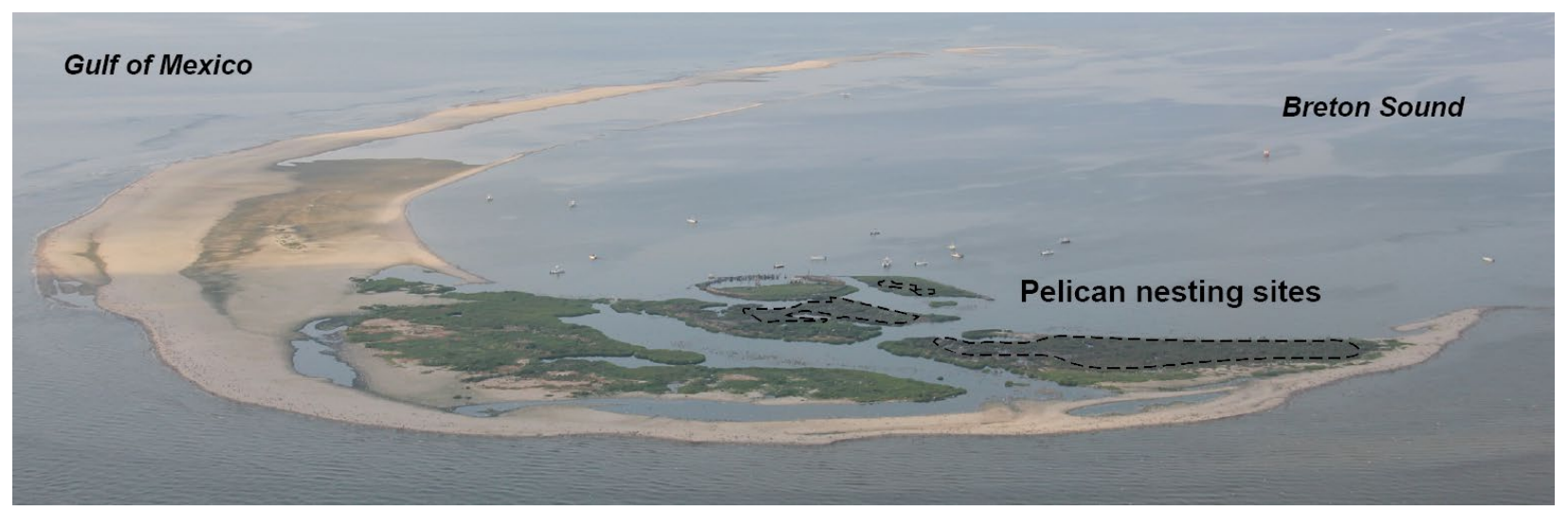

Figure 2. Aerial view of Breton Island from the north showing the prevalent sandy shoreline and the limited pelican nesting habitat within the mangroves on the northern part of the island. Image from Morgan and Westphal (2014a) (collected July 13, 2013). 


\section{History of Breton Island}

Breton and the Chandeleur Islands were designated a wildlife refuge in 1904 to help protect their salt marsh, dunes, barrier island scrub/shrub, and high marsh/upland grass habitats (Penland and others, 1997) for migratory birds and other wildlife species. The islands have been overwashed by multiple storms and are continually reconfigured by tides and waves. On January 3, 1975, the Breton National Wildlife Refuge became part of the National Wilderness Preservation System, which is a combination of state and Federal islands. Although largely natural and undeveloped, oil industry infrastructure is on Breton Island (Penland and others, 1997), providing a notable indication of the influence of human activities.

Breton Island's geomorphic development has been influenced by numerous anthropogenic effects, including dredging. In 1958, the Mississippi River-Gulf Outlet project was started to improve shipping and transport through the Mississippi Delta by creating a 153-meter (m) wide and 11-m deep ship channel from the Mississippi River to the Chandeleur Islands (Penland and others, 1997). Shortly after completion, Breton Island began to experience rapid erosion rates attributed to removal of sediment from the system through maintenance dredging and disposal, and overall reduction in littoral sediment transport across the Mississippi River-Gulf Outlet (Lavoie, 2009). In April 1996, Louisiana State University began the Beneficial Use Monitoring Program, which was designed to create a feeder berm using sand dredged from the Mississippi River-Gulf Outlet to replenish the sand being lost on Breton Island (Penland and others, 1997). Other human influences include the 2010 Deep Water Horizon oil spill, which highlighted the sensitivity of Louisiana barrier islands and marshes to human influence.

\section{Tropical Storm History}

Natural destructive forces, such as major hurricanes and cold fronts, create a cycle of overwash events that continually redistribute sand and reshape Breton Island (Ritchie and Penland, 1988). The National Oceanic and Atmospheric Administration (NOAA) Historic Hurricane Tracks application (http://coast.noaa.gov/hurricanes/, accessed on March 20, 2015) provides a list of tropical storms and data about each storm including a Saffir-Simpson hurricane wind scale (Schott and others, 2012) and a trackline map of storm paths. From this database, a list of hurricanes (category 1 or above at landfall) that passed within 150 kilometers $(\mathrm{km})$ of Breton Island and tropical storms that passed within $10 \mathrm{~km}$ of Breton Island was created (table 1; fig. 3). The distance of $150 \mathrm{~km}$ was used to identify storms with the greatest likelihood of having had an effect on Breton Island; however, storms that passed farther than $150 \mathrm{~km}$ could still have had significant effects on island geomorphology. Storms with documentable effects from the literature, therefore, were also added. Since the 1900s, more than 50 tropical storms of varying strength including nine category 3 or higher hurricanes have affected the southeastern Louisiana coastline (Williams and others, 1992; Yamazaki and Penland, 2001; Stewart, 2004; Knabb and others, 2005; Fearnley and others, 2009; Lavoie, 2009), with 31 of the storms meeting the criteria for having a potential impact on Breton Island (table 1). The frequency and magnitude of storms, in addition to storm trajectory, surge and wave heights, are important considerations when evaluating the effect and influence of past storms.

Hurricane Katrina highlighted the importance of storms on the geomorphic evolution of Louisiana barrier islands. Hurricane Katrina made landfall near the Mississippi River Delta on August 29, 2005, as a category 3 hurricane with wind speeds in excess of 200 kilometers per hour (Knabb and others, 2005). The NOAA buoy number 42040, $112 \mathrm{~km}$ southeast of Breton Island, recorded a maximum wave height of 16.9 meters $(\mathrm{m})$ with a peak period lasting 14.3 seconds. The Chandeleur Islands 
Table 1. Hurricanes passing within 150 kilometers and tropical storms passing within 10 kilometers of Breton Island from 1850 to 2008.

[The "Maximum category within $150 \mathrm{~km}$ of Breton Island" is the highest category the storm reached when it was within $150 \mathrm{~km}$ of Breton Island (unless noted otherwise). The "Storm Direction from Breton Island" column is the general compass heading from Breton Island to the storms eye when the storm passed closest to the island. This heading does not represent the directional movement of the storm. Storm category names: TS, Tropical storm; 1, 2, 3, 4, and 5, hurricane category. Storm date, name and location were downloaded from https://coast.noaa.gov/hurricanes/]

\begin{tabular}{|c|c|c|c|c|}
\hline Year & Landfall date & Name & $\begin{array}{l}\text { Maximum category } \\
\text { within } 150 \mathrm{~km} \text { of } \\
\text { Breton Island }\end{array}$ & $\begin{array}{l}\text { Storm direction from } \\
\text { Breton Island }\end{array}$ \\
\hline 1872 & July 11 & Unnamed (no.1) & TS & East. \\
\hline 1889 & Sept. 23 & Unnamed (no.7) & $\mathrm{TS}$ & Southeast. \\
\hline 1893 & Oct. 02 & Unnamed (no.10) & 3 & West. \\
\hline 1897 & Sept. 12 & Unnamed (no.2) & 1 & South. \\
\hline 1900 & Aug. 12 & Unnamed (no.4) & $\mathrm{TS}$ & West. \\
\hline 1901 & Aug. 18 & Unnamed (no.4) & 1 & Northwest. \\
\hline 1906 & Aug. 27 & Unnamed (no.6) & 2 & East. \\
\hline 1912 & Sept. 14 & Unnamed (no.4) & 1 & East. \\
\hline 1915 & Sept. 29 & Unnamed (no.6) & 3 & West. \\
\hline 1916 & July 05 & Unnamed (no.2) & 2 & East. \\
\hline 1917 & Sept. 28 & Unnamed (no.4) & 2 & East. \\
\hline 1932 & Sept. 01 & Unnamed (no.3) & 1 & Northeast. \\
\hline 1944 & Sept. 10 & Unnamed (no.7) & TS & West. \\
\hline 1947 & Sept. 19 & Unnamed (no.4) & 1 & Directly over Breton Island. \\
\hline 1950 & Aug. 31 & Baker & 1 & East. \\
\hline 1955 & Aug 01 & Brenda & TS & Directly over Breton Island. \\
\hline 1956 & Sept. 24 & Flossy & 1 & Southeast. \\
\hline 1960 & Sept. 16 & Ethel & 4 & East. \\
\hline 1965 & Sept. 10 & Betsy & 4 & West. \\
\hline 1969 & Aug. 18 & Camille & 4 & West. \\
\hline 1979 & Sept. 13 & Frederic & 3 & West. \\
\hline 1985 & Sept. 02 & Elena & 2 & North. \\
\hline 1988 & Aug. 08 & Beryl & TS & West. \\
\hline${ }^{1} 1992$ & Aug. 08 & Andrew & 3 & West. \\
\hline${ }^{1} 1995$ & Oct. 04 & Opal & 3 & West. \\
\hline${ }^{1} 1996$ & Oct. 07 & Josephine & TS & Southeast. \\
\hline${ }^{2} 1997$ & July 07 & Danny & $\mathrm{TS}$ & North. \\
\hline 1998 & Aug. 28 & Georges & 1 & East. \\
\hline 12002 & Sept. 26 & Isidore & TS & West. \\
\hline 2004 & June 16 & Ivan & 3 & East. \\
\hline 2005 & Aug. 29 & Katrina & 4 & West. \\
\hline 2008 & Sept. 01 & Gustav & 1 & West. \\
\hline
\end{tabular}

${ }^{1}$ Outside $150 \mathrm{~km}$ hurricane buffer but added because of known impacts on Breton Island (Isidore, 2003; Andrew, 2012; Opal, 2015).

${ }^{2}$ Outside $10 \mathrm{~km}$ tropical storm buffer but added because of known effects on Breton Island (Creef and others, 2003). 
were completely inundated during Hurricane Katrina and became temporary shoals that experienced large area loss and landward migration (Sallenger and others, 2009). Although Hurricane Katrina was a large and powerful storm, smaller storms have the ability to affect barrier island geomorphology as well (Kahn and Roberts, 1982; Penland and others, 1988; Stone and others, 2005). The effect of storms on barrier islands are not only dependent on the storm surge, waves, and wave run-up but also upon the storm path and geometry of the barrier island (Sallenger, 2000); for example, in northern advancing hurricanes, the greatest wind speeds and the most devastating damage happen on the eastern side of the hurricane eye (Houston and others, 1999; Fearnley and others, 2009). This was the case with hurricanes Katrina (2005) and Camille (1969) where the eastern side of both storms passed directly over Breton and Chandeleur Islands (Fearnley and others, 2009). The direction, intensity, and duration of the storm can cause a storm surge that inundates a barrier island and moves large amounts of sediment in a matter of hours (Fritz and others, 2007).

Overwash and inundation events have the ability to remove dunes and vegetation, but they can also add fine sand to barrier islands. These fine sands are susceptible to aeolian processes and island migration (Ritchie and Penland, 1988). In some circumstances, storms can transport sediments from deeper ocean waters to nearshore waters, making sediments available for reworking by waves resulting in barrier island recovery (Stone and others, 2004). Once the storm has passed, milder waves and wind rebuild and rework the island. Storms can also introduce seeds and rhizomes, which can take root and stabilize sediments (Ritchie and Penland, 1988). Given enough time and sufficient sediment supply, barrier islands can recover after the passage of a storm; however, the combined effects of human alterations to the sediment supply and accelerated sea-level rise can reduce resilience of barrier islands to storm recovery.
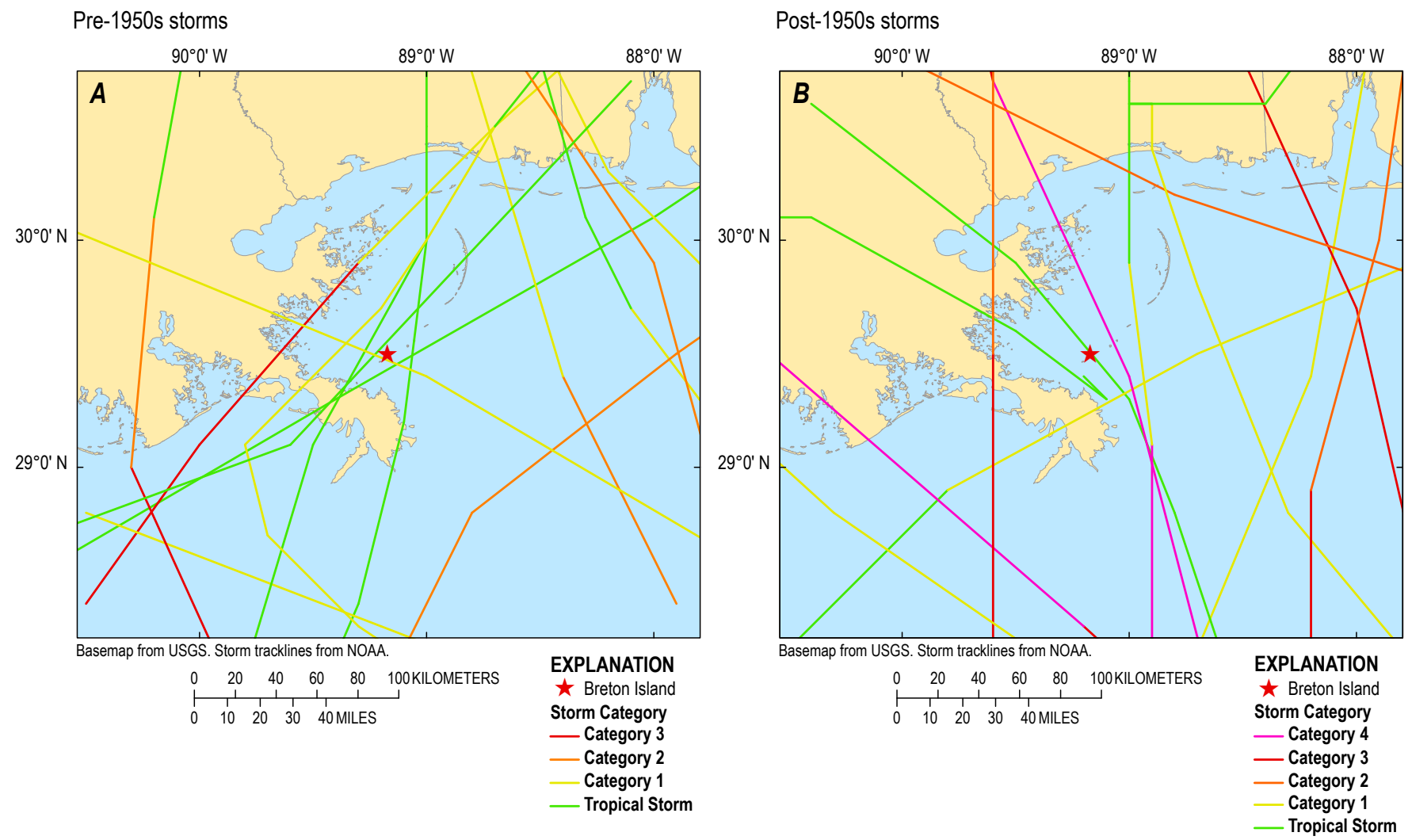

Figure 3. Tracklines of major hurricanes passing within 150 kilometers and tropical storms passing within 10 kilometers of Breton Island. $A, 1870$ to 1949. B, 1950 to 2008. 


\section{Mapping Shoreline Change}

Historical coastal maps provide a record of shoreline position and coastal topography and can be used to examine shoreline changes with time. From 1834 to the 1970s, the U.S. Coast and Geodetic Survey created highly detailed topographic sheets (T-sheets) (Shalowitz, 1964). T-sheets were hand drawn and surveyed in the field using a plane table. The NOAA scanned the T-sheets into digital format and digitized vector shoreline features (http://www.shoreline.noaa.gov/data/datasheets/t-sheets.html). Shorelines derived from T-sheets are subject to a number of errors and uncertainties because of positional accuracy, antiquated mapping techniques, and scanning/digitization; however, they provide an authoritative source of historical shoreline position at the time of survey and provide the most accurate high-water line position possible (see Crowell and others [1991] and Shalowitz [1964] for more information on historical mapping methods and T-sheet accuracy).

The introduction of aerial imagery improved topographic and shoreline mapping by reducing the need to collect extensive and time-intensive field measurements. Aerial imagery has been collected from the late 1930s to the present and provides a source for shoreline position. Shorelines can be digitized from three image types (from most to least accurate): stereoscopic images (a 3-dimensional map using adjacent overlapping images), orthorectified images (orthorectification removes the effects of image perspective and relief effects for a planimetrically correct image), and rectified aerial images (images are geographically mapped and corrected using known control points). Shorelines derived from aerial imagery are affected by water levels at the time of image capture and human interpretation of shoreline features. Shorelines can be interpreted from other visible features such as vegetation lines, sediment type or color changes, erosional scarps, and wet/dry lines, which can introduce spatial uncertainty (Anders and Byrnes, 1991; Crowell and others, 1991; Morton, 1991).

For the past two decades, airborne topographic light and detection ranging (lidar) surveys are the most common method for deriving shoreline position. Lidar measures ground elevation with vertical and horizontal accuracy of plus or minus $( \pm) 15$ centimeters $(\mathrm{cm})(0.15 \mathrm{~m})$ and $3 \mathrm{~cm}$, respectively. It can be used to extract shorelines based on an elevation value, such as high water (HW) or mean high water (MHW) (Sallenger and others, 2003). Lidar can reduce shoreline errors and uncertainty because it uses specific elevation values for a given area to contour a vector shoreline (Stockdon and others, 2002). Lidar-derived shorelines often have less uncertainty than image derived shorelines because they do not rely on image interpretation and hand-digitization. Lidar surveys can also include a bathymetric component, as was the case in the 2014 survey, but the shoreline can still be defined.

\section{Methods}

This study builds on previous shoreline change analyses completed through the Barrier Island Comprehensive Monitoring (BICM) Project, a comprehensive study of Louisiana's barrier islands (Kindinger and others, 2013). Shoreline, area, and volume change for Breton Island were examined using T-sheets, aerial imagery and topographic lidar (fig. 4) from 14 dates between 1869 to 2014 (table 2). Historic T-sheets provided data for shoreline positions from 1869 to the $1950 \mathrm{~s}$. Aerial imagery was used to extract data from the 1970s to 2012. The aerial imagery was obtained from the following: Digital Orthophoto Quadrangle, National Agriculture Imagery Program, and National High Altitude Photography. Shorelines were determined from lidar data for three dates: 2001 (Yates and others, 2009), 2013 (Guy and Plant, 2014), and 2014 (Terrano and others, 2016). Although 2007 lidar data are available, they were previously digitized from aerial imagery. This shoreline was used; however, it was checked against the 2007 lidar data for positional accuracy. 


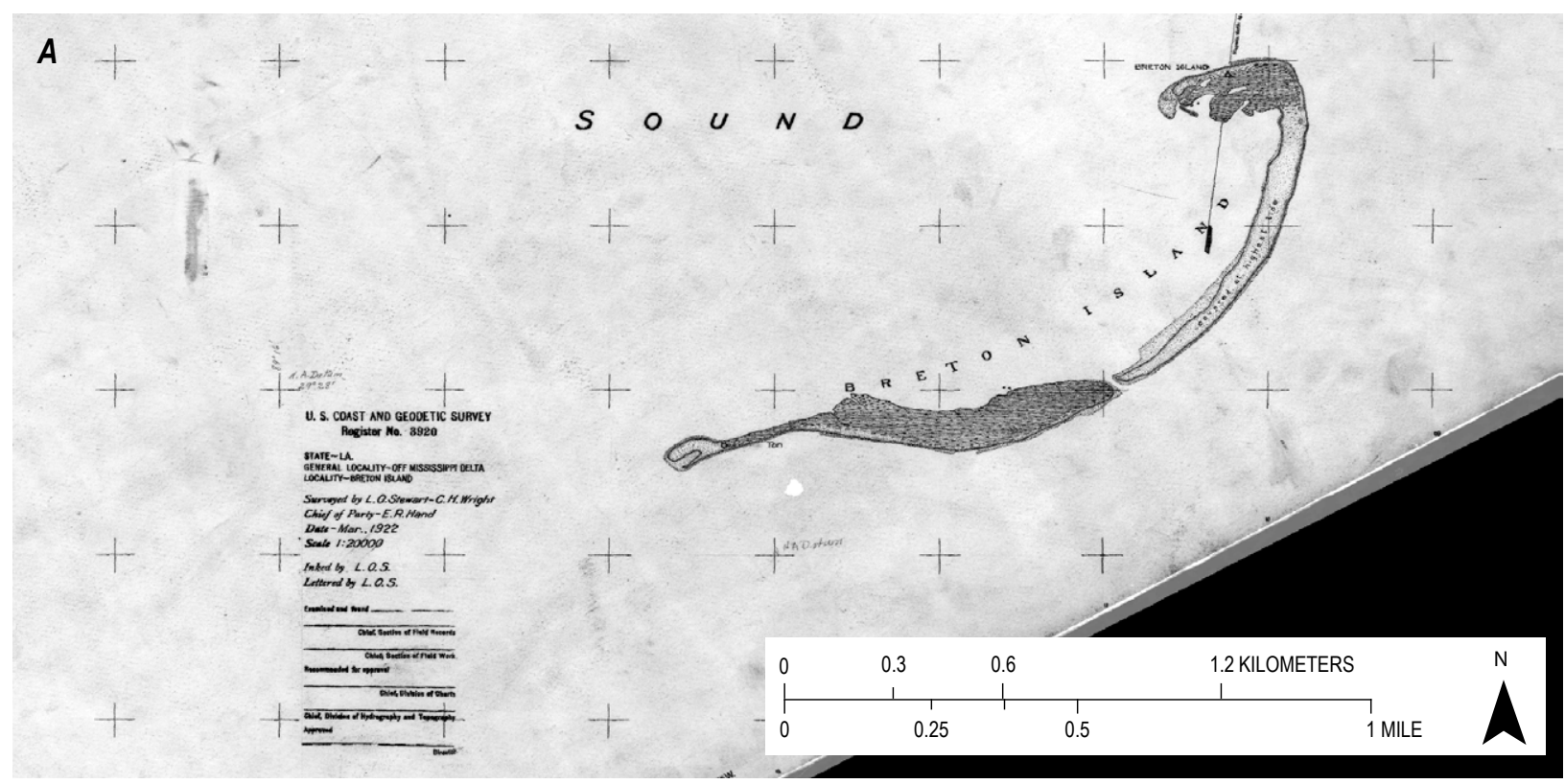

Shoreline, 2015

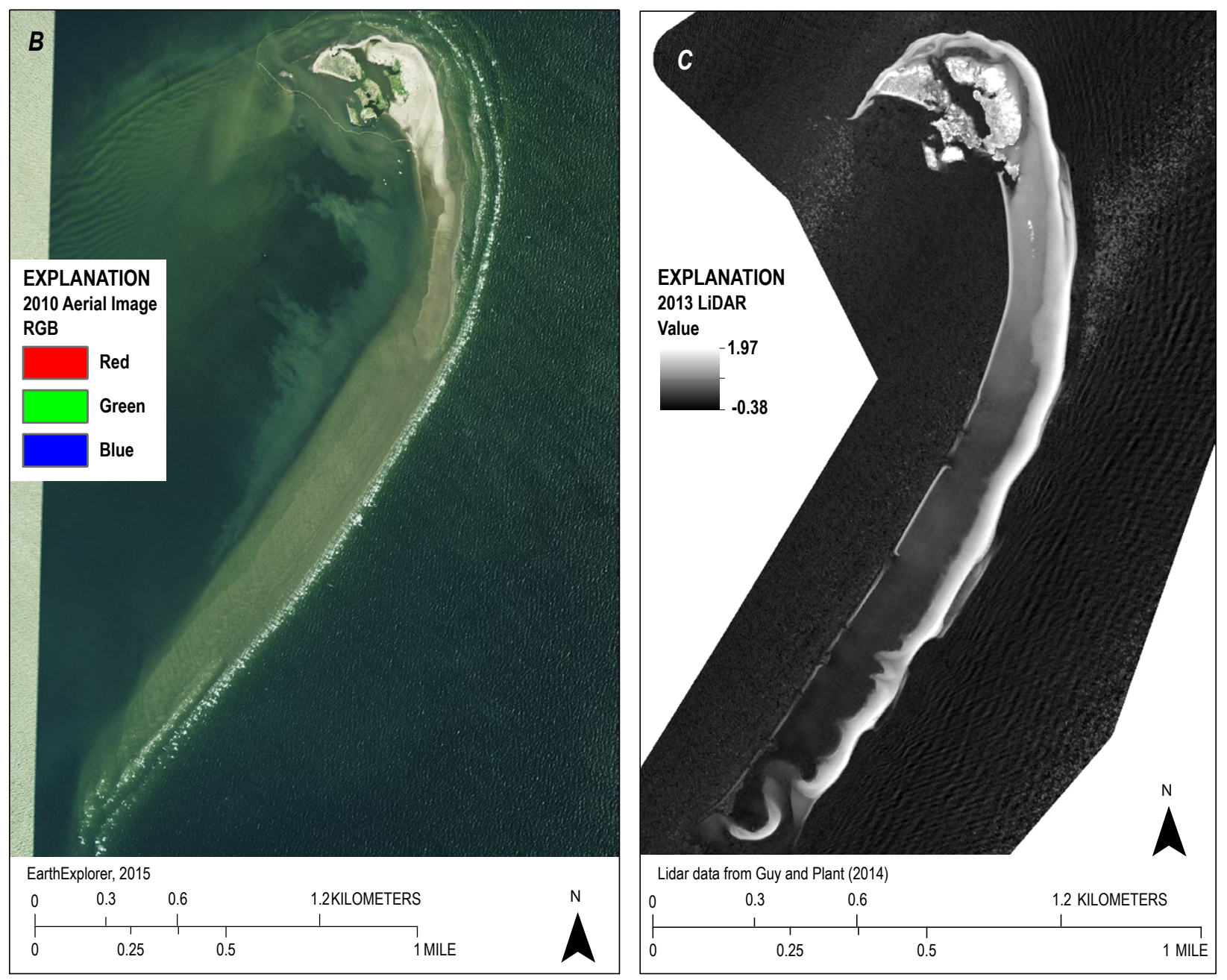

Figure 4. Examples of the three data types used to derive shorelines. A, National Oceanic and Atmospheric Administration topographic sheet from 1869. B, aerial image from 2010. C, light and detection ranging dataset from 2013. 
Table 2. Sources of imagery used in the determination of shoreline positions for Breton Island, Louisiana.

[Imagery type abbreviations: B\&W, black and white; CIR, color infrared; T-sheet, topographic sheet; NHAP, national high altitude photography; DOQ, digital orthophoto quadrangle; HRO, high resolution orthoimagery; NAIP JPG2000, National Agricultural Imagery Program in the JPG2000 format]

\begin{tabular}{|c|c|c|c|c|}
\hline Year & Imagery type & $\begin{array}{l}\text { Uncertainty } \\
\text { (meters) }\end{array}$ & Imagery producer & Source \\
\hline 1869 & T-sheet & 10.8 & U.S. Coast and Geodetic Survey & ${ }^{1} \mathrm{NOAA}$ \\
\hline 1922 & T-sheet & 10.8 & U.S. Coast and Geodetic Survey & ${ }^{1} \mathrm{NOAA}$ \\
\hline 1950 & T-sheet & 10.8 & U.S. Coast and Geodetic Survey & ${ }^{1} \mathrm{NOAA}$ \\
\hline 1983 & B\&W NHAP aerial imagery & 3.2 & U.S. Geological Survey & ${ }^{2}$ USGS. \\
\hline 1998 & CIR DOQ aerial imagery & 3.2 & U.S. Geological Survey & ${ }^{2}$ USGS. \\
\hline 2001 & Lidar & 1.9 & U.S. Geological Survey & ${ }^{3}$ USGS. \\
\hline 2004 & CIR DOQ aerial imagery & 3.2 & U.S. Geological Survey & ${ }^{2}$ USGS. \\
\hline 2005 & CIR DOQ aerial imagery & 3.2 & U.S. Geological Survey & ${ }^{2}$ USGS. \\
\hline 2007 & $\begin{array}{c}\text { CIR NAIP JPG2000 aerial } \\
\text { imagery }\end{array}$ & 3.2 & U.S. Department of Agriculture & ${ }^{2}$ USGS. \\
\hline 2008 & CIR HRO aerial imagery & 3.2 & U.S. Geological Survey & ${ }^{2}$ USGS. \\
\hline 2010 & $\begin{array}{l}\text { CIR NAIP JPG2000 aerial } \\
\text { imagery }\end{array}$ & 3.2 & U.S. Department of Agriculture & ${ }^{2}$ USGS. \\
\hline 2012 & CIR HRO aerial imagery & 3.2 & U.S. Geological Survey & ${ }^{2}$ USGS. \\
\hline 2013 & Lidar & 1.9 & U.S. Geological Survey & ${ }^{4}$ USGS. \\
\hline 2014 & Lidar & 1.9 & U.S. Geological Survey & ${ }^{5}$ USGS. \\
\hline
\end{tabular}

1 Shoreline, 2015

2 EarthExplorer, 2015

${ }^{3}$ Yates and others, 2009

${ }^{4}$ Guy and Plant, 2014

5 Terrano and others, 2016

The U.S. Geological Survey (USGS) oblique aerial images of Breton Island collected from aircraft flying at low altitudes provided additional information that was useful in shoreline verification. These images are generally collected before and after a major storm to document storm-induced changes to the island. Exact shoreline position cannot be identified from oblique imagery because of variance in the distance, height, and angle of the camera; however, the surf zone is visible and can be compared to other imagery where submergence or the location of the MHW zone is uncertain. Another way to use this type of imagery is to compare images from different days, months, or years to document changes on a short- and long-term basis (fig. 5). Though oblique imagery was not used to quantify shoreline change rates, oblique aerial imagery was used as a tool to assess the accuracy of certain digitized shorelines.

Shoreline data were processed using Environmental Systems Research Institute, Inc. (Esri) ArcGIS software version 10.2.2, (http://www.esri.com/software/arcgis). Island area and shoreline length measurements were calculated using XTools Pro 11.1328, (https://xtools.pro/en/overview/). Shoreline rate-of-change statistics were calculated using Digital Shoreline Analysis Systems (DSAS) version 4.3 (http://woodshole. er.usgs.gov/project-pages/DSAS/), a software extension for Esri ArcGIS (Thieler and others, 2009). Analyses involved several data preparation steps, including data acquisition, projection conversion, table preparation, baseline and transect construction, and generation of statistics. All shorelines were projected into Universal Transverse Mercator (UTM) zone 16N, North American Datum of 1983 (NAD 83) as required by DSAS. 

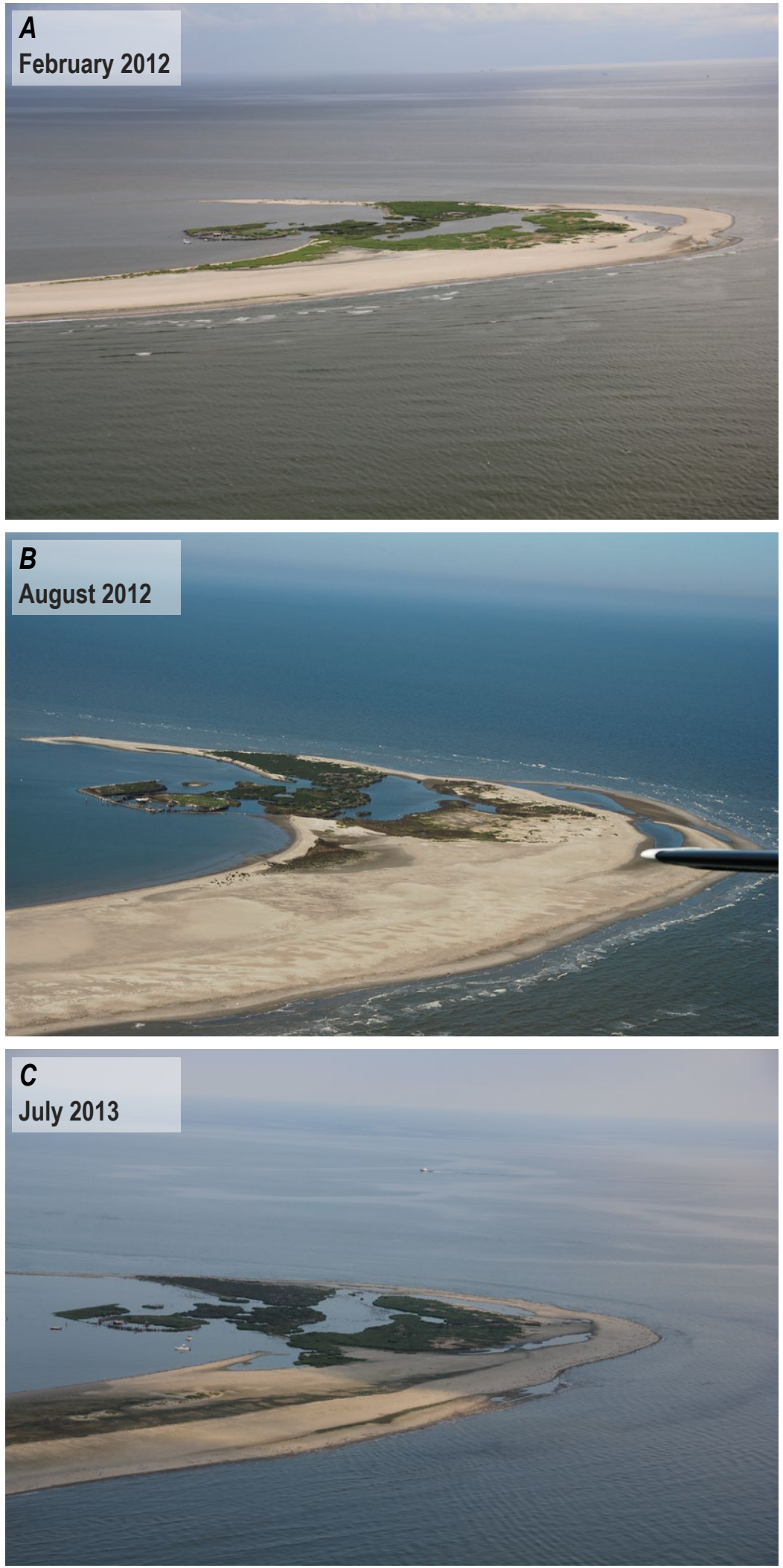

Figure 5. Comparison of oblique aerial imagery for February 2012, August 2012, and July 2013. The oblique aerial imagery was used to verify ground features identified in the main imagery types (fig. 3). Images from Morgan and others (2013) and Morgan and Westphal (2014a, 2014b). 


\section{Shoreline Data Compilation}

Georeferenced T-sheets and vector shorelines derived from the T-sheets were downloaded from the NOAA Historical Shoreline tool (http://www.shoreline.noaa.gov/data/datasheets/t-sheets.html) and visually compared for positional accuracy. The T-sheets used for this study were: T-1097 (1869), T-3920 (1922), and T-9393 (1950) (table 2).

Aerial imagery, dating from 1970 to 2012, was downloaded from EarthExplorer (http:// earthexplorer.usgs.gov/). Refer to table 2 for a complete list of aerial image dates, source, and estimated uncertainty (discussed in more detail in this section). Shorelines from each imagery dataset were "heads-up digitized" in Esri ArcMap using the Editor Toolbar and Create Features tool. The images were first reprojected into UTM coordinates, if necessary, and then individual entire island shorelines were identified and digitized. The shorelines were checked for quality, and errors were corrected. The 1983 black-and-white aerial photos downloaded from EarthExplorer were not georeferenced; therefore, before digitization, the imagery was georeferenced using the ArcMap Georeference toolbar. The image corner coordinates specified in the image metadata and observable island infrastructure were used for control points. This georeferencing process may have increased shoreline position error, and error estimates for the 1983 shoreline were difficult to calculate. A small offset in the 2007 imagery was detected by comparing the location of a nearby oil platform to other imagery; therefore, before digitization, the 2007 imagery was adjusted by calculating the exact distance and direction of the offset and using the ArcToolbox Shift tool to make it more geographically consistent with the other imagery. The shoreline was then able to be digitized.

Three lidar raster datasets, represented as digital elevation models, with coverage of Breton Island provided additional shoreline positions for 2001, 2013 and 2014. The MHW elevation for the Chandeleur barrier island chain is estimated to be 0.37 North American Vertical Datum of 1988 (NAVD 88) (GEOID99) for 2001 and 0.23 meters NAVD 88 (GEOID12a) for 2013 and 2014 (Morton and others 2004), and was used as a proxy for the shoreline position. The lidar raster datasets were classified into two categories in ArcMap using the MHW value as the break. Class 1 was elevations below the MHW, and class 2 was elevations at or above the MHW. Classifying the lidar raster datasets as such produced a binary image delineating the MHW line (fig. 6). The MHW line was then vectorized in ArcMap using the ArcToolbox tool Contour List. The raster data and MHW value were input and resulted in the creation of a line representing the shoreline (fig. 6). In some cases inland areas with the MHW elevation value were vectorized, so to maintain consistency with what shorelines were present for the final analysis they were removed as needed.

Following digitization, or vectorization, shorelines were customized for shoreline change analyses. Each shoreline dataset was attributed with the data source date, checked for errors, and edited. Topology was created for each polyline, and five rules were used to check and ensure one contiguous line. Topology rules were as follows: (1) the shoreline must not have dangles, (2) must not intersect, (3) must not overlap, (4) must not self-intersect, and (5) must not self-overlap. Using the Validate Topology tool, an error file was generated and added to the map, which identified the location of all errors. Errors were identified and fixed before conversion of polyline features to island polygon. The northern-most and southern-most parts of the shorelines were used as break-points delineating the foreshore and backshore (the eastern, or Gulf, shoreline being the foreshore and the western, or Sound, shoreline the backshore) and attributed as such in the attribute table. The lengths of the foreshore and backshore were calculated using XTools Calculate Geometry tool. Separating the shorelines enabled an evaluation of shoreline length for foreshore and backshore with time. The shorelines were also converted to polygon features for use in the island area analysis. 
All derived shoreline positions have sources of error that must be taken into account when calculating shoreline change rates. This uncertainty is dependent on the source data; and steps involved from data collection, georeferencing, digitization, and analysis. For this study, lidar provided the most accurate estimation of shoreline position, followed by aerial imagery, and lastly, T-sheets. Aerial imagery can be classified into two general groups, orthorectified (planimetrically corrected for perspective and relief) and georeferenced (associated within geographic space but not planimetrically corrected); the former is generally the most spatially accurate. Previous studies, such as Morton and others (2004) and Hapke and others (2010), have attempted to provide a general error value for the uncertainty or level of accuracy expected for each of the data sources, depending on the data source and geographic location. The uncertainty values used in this study were obtained from E.A. Himmelstoss, (U.S. Geological Survey, written commun., 2016), as a numeric value, when applicable. The values used here are slightly different than those used in previous studies because they take into account new mapping techniques and localized fluctuation in MHW level. Lidar-derived shoreline uncertainty values in this study represent Breton Island specifically and are not a generalized average for the Gulf of Mexico, such as the case for the T-sheet or aerial image-derived shoreline values.

\section{Shoreline Change Analysis}

The DSAS (Thieler and others, 2009) is a software extension for ArcGIS that calculates shoreline change as described below. For this analysis, version 4.3.4730 was used with ArcGIS 10.0 (Thieler

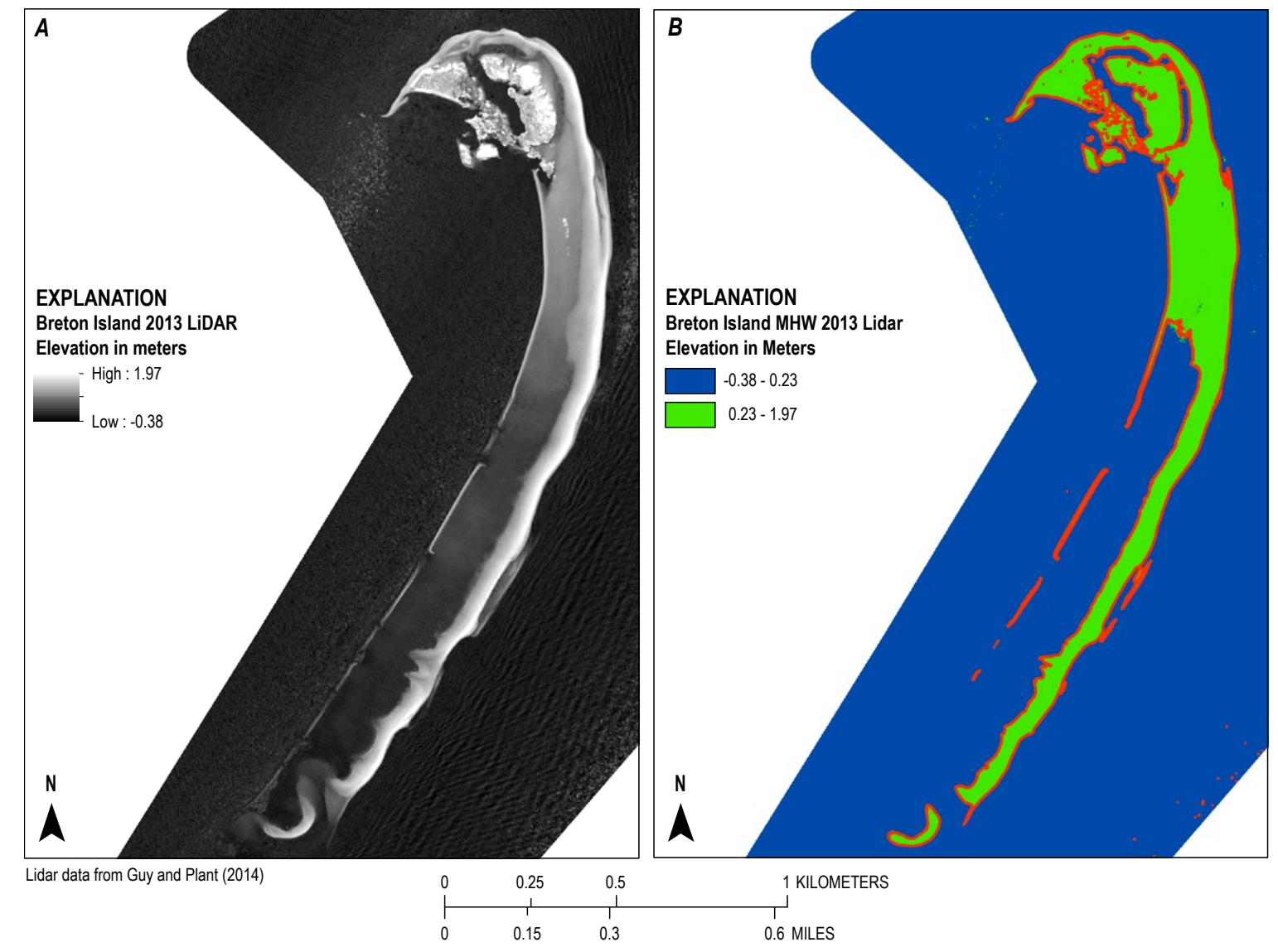

Figure 6. Representation of light and detection ranging (Lidar) data of Breton Island, 2013. A, Lidar data represented as a digital elevation model. B, Lidar data classified as above or below the mean high water $(0.23 \mathrm{~m})$ and the derived vectorized shoreline. 
and others, 2009). Because of complications with DSAS compatibility and current versions of ArcMap (10.1 and above), ArcMap 10.0 was used only for DSAS analysis, and all other data manipulations and processing were done in ArcGIS 10.2.2. The DSAS uses spatial uncertainly for calculating weighted regression and uncertainty values were assigned based on source type and year from previously published estimates of data source errors (table 2) (E.A. Himmelstoss, U.S. Geological Survey, written commun., 2016). The DSAS also uses the date of the data. If known, the date that the data were collected was used. If only the year was known, January 1st was used.

Analysis was done on the foreshore for multiple periods: 1869-2014 (long term), pre-1950 (before excavation of the Mississippi River-Gulf Outlet), post-1950 (post-Mississippi River-Gulf Outlet), post-Hurricane Katrina (short term), and pre/post-Hurricane Katrina (acute weather event). Dividing the data into multiple analysis windows allowed the comparison of shoreline change rates over time and for specific events. The foreshore shorelines used are illustrated in figure 7.

In addition to the shorelines, the DSAS also uses baselines and transects to locate positions from which to calculate statistics. Baseline and transect files were acquired from the BICM Project (Martinez and others, 2009). Transects were generated at a 50-m interval perpendicular to the baseline, 211 transects in all, covering the length of Breton Island (Martinez and others, 2009). The same baseline and transects were used for each analysis window so shoreline change rates would be calculated at the same spatial locations.

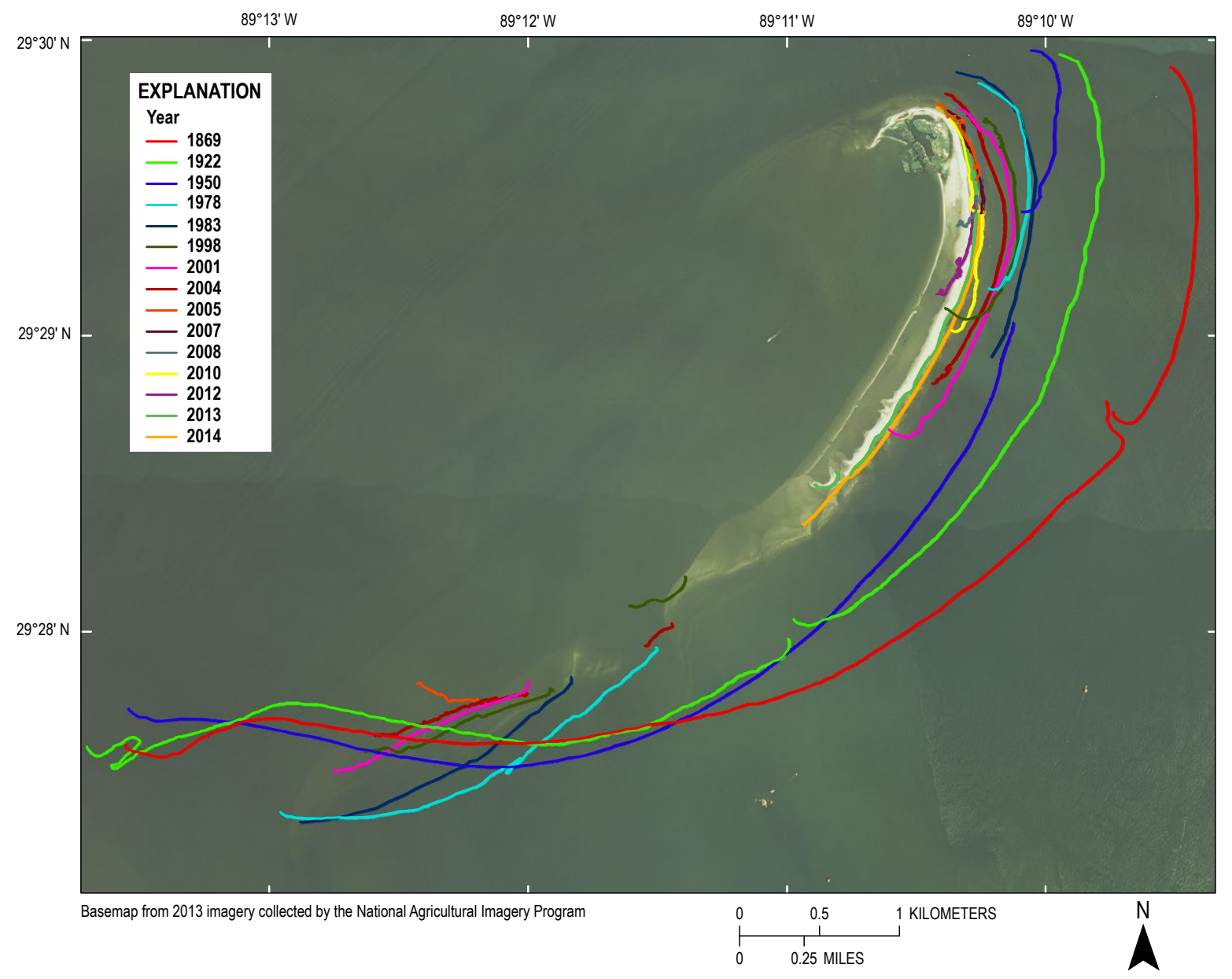

Figure 7. Foreshore shoreline positions for Breton Island from 1869 to 2014. 
The DSAS calculates numerous shoreline distance, rate-of-change, and confidence statistics (table 3) (Thieler and others, 2009). The statistics calculated by the DSAS for this study include the following: (1) net shoreline movement (NSM), (2) shoreline change envelope (SCE), (3) end point rate (EPR), (4) linear regression rate (LRR), (5) R-squared of linear regression rate (LR2), and (6) weighted linear regression rate (WLR). The first two statistics, NSM and SCE, are the distances of shoreline movement, and the other three are rates of shoreline movement.

The NSM is the net distance (in meters) between the oldest and the most recent shorelines at each transect. The NSM can be positive or negative, indicating an accreting or eroding shoreline, respectively, within the analysis window. The SCE is the distance (in meters) between the shorelines closest and farthest from the baseline at each transect regardless of the date. The SCE is the greatest distance within the analysis window regardless of whether the process is erosion or accretion.

Shoreline change rates, such as EPR and LRR, take into account both the measured distance of change as well as the time period. The EPR (in meters per year) measures the distance between the most recent and oldest shoreline divided by the time between the two shorelines. The EPR requires only two shorelines (the youngest and oldest) and is a simple metric of overall change; however, it ignores the useful information provided by additional shoreline data, which may involve different rates. In comparison, the LRR (in meters per year) uses all available shoreline data. It is a statistically derived rate-ofchange that computes least-squares regression line fitted to all available data for each transect. The LRR is equivalent to the slope of the regression line. The WLR (in meters per year) is similar to the LRR; however, the regression process adds more weight towards data with greater certainty, thereby weighting the change rate toward more accurate shoreline positions. The LR2 represents a statistical measure of how close the data are to the fitted regression line. Values close to zero indicate a highly variable dataset, whereas values closer to one represent a more accurate (less variable) dataset.

Supplemental statistics include both the 90-percent confidence interval and R-squared $\left(R^{2}\right)$ values for change rate statistics. The additional data provide information on the robustness of the computed regression statistic. A more detailed description of each statistic and specific equations can be found in the DSAS 4.0 user manual (Thieler and others, 2009). A complete analysis of supplemental statistics are not available in this report, but can be acquired from the data release (Terrano and others, 2015).

The three criteria used to assess the reliability of shoreline change rates were the following: (1) variability in shoreline positions as a result of sampling errors, (2) errors from issues with the measurements of the shoreline positions that are then propagated to shoreline positions accuracy, and (3) errors from statistical calculations when compiling and comparing the data (Anders and Byrnes, 1991; Crowell and others, 1991; Thieler and Danforth, 1994; Moore, 2000; Morton and others, 2004). Shoreline change statistics were summarized by reporting the average rate-of-change for all transects plus or minus the standard error (table 3). Standard error was calculated using the equation:

$$
S E_{\bar{x}}=\frac{s}{\sqrt{n}}
$$

where

$\begin{array}{cl}S E_{\bar{x}} & \text { is the standard error of the mean, } \\ S & \text { is the standard deviation of the mean for each statistic, and } \\ n & \text { is the number of transects used to calculate the statistic. }\end{array}$

Change statistics were not calculated for transects that did not include a minimum number of 
Table 3. Statistical averages by time period.

[Negative values represent erosion while positive values represent accretion. Cells with a "----" denote that there was not enough shoreline data to calculate that statistic. Distances and rates are represented in meters $(\mathrm{m})$ or meters per year $(\mathrm{m} / \mathrm{yr})$. NSM represents net shoreline movement. Abbreviations of rate of change names: EPR, end point rate; SCE, shoreline change extent; LRR, linear regression rate; LR2, R-squared of linear regression; WLR, weighted linear regression]

\begin{tabular}{|c|c|c|c|c|c|c|c|c|c|c|c|c|c|}
\hline & $\begin{array}{c}\text { Number of } \\
\text { transects used }\end{array}$ & NSM (m) & $\begin{array}{c}\text { NSM standard } \\
\text { error }\end{array}$ & $\begin{array}{l}\text { EPR } \\
(\mathrm{m} / \mathrm{yr})\end{array}$ & $\begin{array}{c}\text { EPR standard } \\
\text { error }\end{array}$ & SCE $(m)$ & $\begin{array}{c}\text { SCE standard } \\
\text { error }\end{array}$ & $\begin{array}{l}\text { LRR } \\
\text { (m/yr) }\end{array}$ & $\begin{array}{c}\text { LRR standard } \\
\text { error }\end{array}$ & $\begin{array}{l}\text { LR2 } \\
\text { (m/yr) }\end{array}$ & $\begin{array}{c}\text { LR2 standard } \\
\text { error }\end{array}$ & $\begin{array}{l}\text { WLR } \\
(\mathrm{m} / \mathrm{yr})\end{array}$ & $\begin{array}{l}\text { WLR standard } \\
\text { error }\end{array}$ \\
\hline $1869-2014$ & 192 & -695 & \pm 43.78 & -5 & \pm 0.32 & 846 & \pm 35.51 & -5 & \pm 0.33 & 0.74 & \pm 0.02 & -7 & \pm 0.38 \\
\hline Pre-1950 & 192 & -381 & \pm 30.26 & -5 & \pm 0.41 & 464 & \pm 24.18 & -4 & \pm 0.39 & 0.71 & \pm 0.03 & --- & --- \\
\hline Post-1950 & 146 & -364 & \pm 21.54 & -7 & \pm 0.52 & 502 & \pm 8.94 & -7 & \pm 0.55 & 0.78 & \pm 0.02 & -11 & \pm 0.54 \\
\hline $\begin{array}{c}\text { Pre-/Post- } \\
\text { Hurricane Katrina }\end{array}$ & 21 & -130 & \pm 12.30 & -72 & \pm 6.75 & 130 & \pm 12.30 & --- & --- & --- & --- & --- & --- \\
\hline $\begin{array}{l}\text { Post- } \\
\text { Hurricane Katrina }\end{array}$ & 68 & 5 & \pm 6.32 & 29 & \pm 5.14 & 79 & \pm 6.32 & -9 & \pm 1.62 & 0.31 & \pm 0.04 & -7 & \pm 3.36 \\
\hline
\end{tabular}


shorelines required for computation. The LRR and WLR require at least three shoreline dates, whereas EPR, SCE, and NSM require only two shoreline dates. There were various reasons why some areas had too few shorelines, including the following: (1) inlet openings, (2) missing data, (3) barrier island migration, and (4) shoreline loss (Morton and Others, 2004). For Breton Island, the most frequent reason was barrier island submergence or shoreline loss. The number of transects was adjusted accordingly in the average calculations to reduce their impact on overall results.

\section{Island Area Analysis}

Examining total land area change with time for a barrier island can provide additional information on geomorphic changes and storm response. Total island area was calculated from the shoreline polygon features generated for each of the 12 dates (1869-2014) (fig. 8). The polygons were generated from the shoreline line feature using the XTools Make Polygons from Polylines tool, which converts closed line features to polygon features. The area in square kilometers for each polygon was calculated and added to the attribute table using the XTools Calculate Geometry tool.

Island area values from other publications (McBride and others, 1992; Penland and others, 1997) were converted to square kilometers and included in plots of island area that were generated using Excel 2010. Plots for 1869-2014 (long term) and 2001-14 (recent) are in figure 9.

\section{Elevation Change Analysis}

Elevation change analysis was completed using four lidar elevation datasets available for Breton Island collected in 2001, 2007, 2013, and 2014. All data were published in the same horizontal (UTM NAD 83) and vertical datum (NAVD 88); however, the 2001 data were available in the 1996 GEOID model. The VDatum software version 3.4 (http://vdatum.noaa.gov/), therefore, was used to convert the 2001 lidar data from GEOID96 to GEOID12A, to match the 2013 and 2014 lidar datasets (National Geodetic Survey, 2014). Elevation change rasters were calculated using the Raster Calculator tool. The oldest date was subtracted from the most recent date (for example, 2007-2001). The resulting raster produces a map of elevation loss and gain as negative and positive values, respectively. Lidar data have an estimated vertical accuracy of $15 \mathrm{~cm}$; therefore, a conservative estimate of elevation change would be change greater than $30 \mathrm{~cm}$ or less than $-30 \mathrm{~cm}$. In 2001, a breach divided Breton Island into two islands; however, for all subsequent years, the southern segment was submerged and is therefore ignored in change analyses.

Island sediment volume above the MHW elevation (0.23 m NAVD 88) was calculated for all four lidar dates using the Surface Volume (3D Analyst) tool in ArcGIS. The MHW was chosen as the starting elevation to remove submerged areas, primarily in the 2014 lidar, so that the unwanted data were not included in the final results. For 2001, the volume estimate was calculated for the northern and southern island parts to make direct comparisons of northern parts volume changes with time.

\section{Results and Discussion}

\section{Land Area Change}

Breton Island temporal shoreline comparison shows a general trend of island narrowing and westward migration (fig. 8). Most datasets show a breach in Breton Island, although the location of the breach changes with time. In 1869, shoreline data display the breach toward the northern part of Breton 
Island. By 1922, the breach was farther south, perhaps because of wave reworking. By 1950, the breach is farther north, then by 1983 , the breach is again farther south but has widened substantially and shows two distinct island areas, which will be referred to as the north and south island. In general, the island has migrated west, with the greatest movement happening along the north island.

Breton Island land area and shoreline length calculations from data used in this study indicate significant land and shoreline loss since 1869 (fig. 9; table 4). In 1869, island area was 3.3 square kilometers $\left(\mathrm{km}^{2}\right)$ with a shoreline of more than $30 \mathrm{~km}$ in total length. Recent 2014 data indicate that the southern island is largely submerged, and the northern part has been reduced to $0.43 \mathrm{~km}^{2}$, a reduction of nearly $2.9 \mathrm{~km}^{2}$ or 87 percent from the 1869 land area (table 4). The rate of land loss from 1869 to 2014 is estimated at 0.02 square kilometers per year $\left(R^{2}=0.85\right)$, although the rate of land area change is not constant (fig. 9). The smallest land area was documented in $2007\left(0.14 \mathrm{~km}^{2}\right)$, and recent trends exhibit a slow increase in island area to $0.43 \mathrm{~km}^{2}$, possibly resulting from an absence of significant storms during this period.

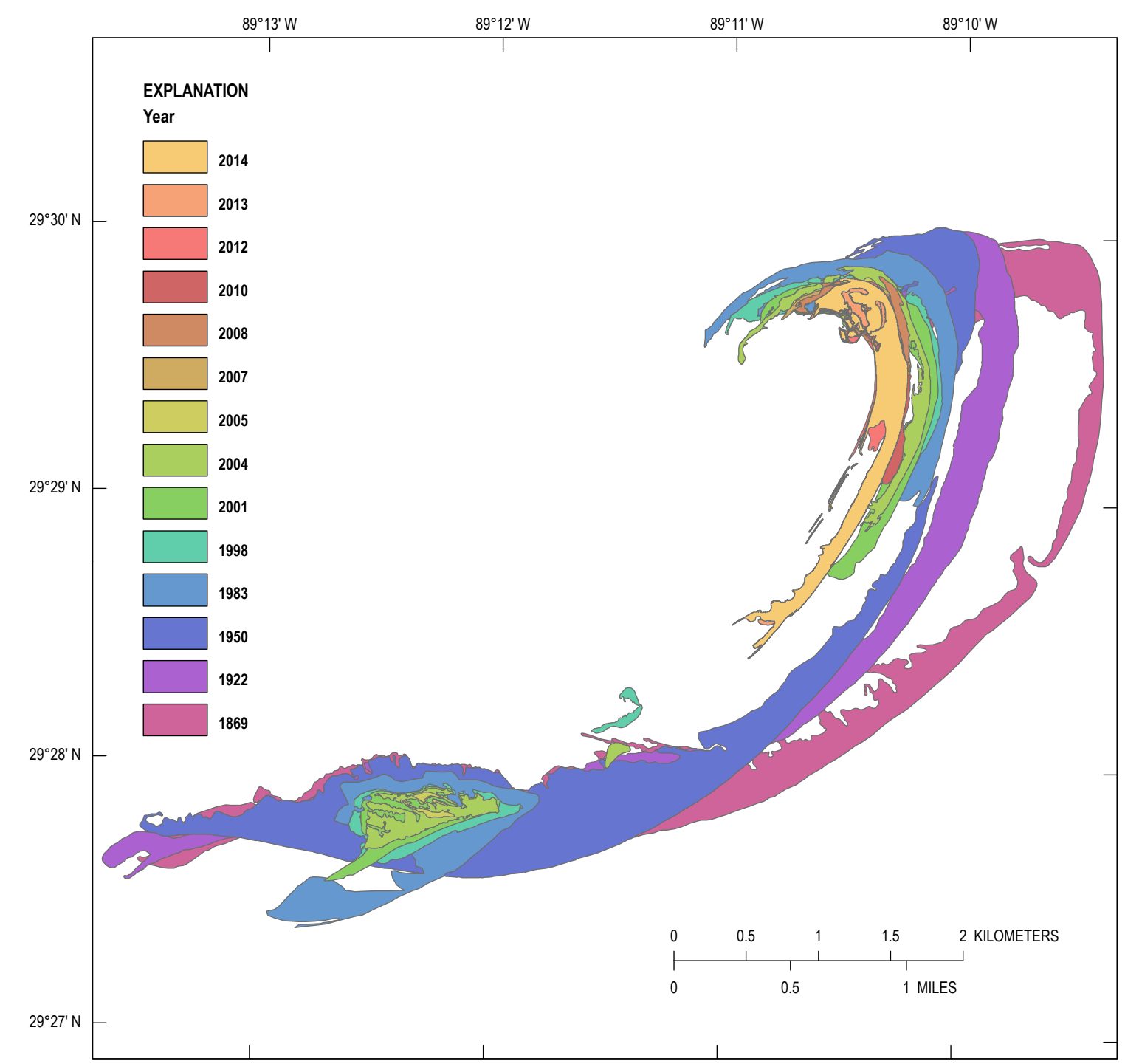

Figure 8. All island area polygons mapped to show how the geometry and geographic orientation of Breton Island has changed from 1869 to 2014 


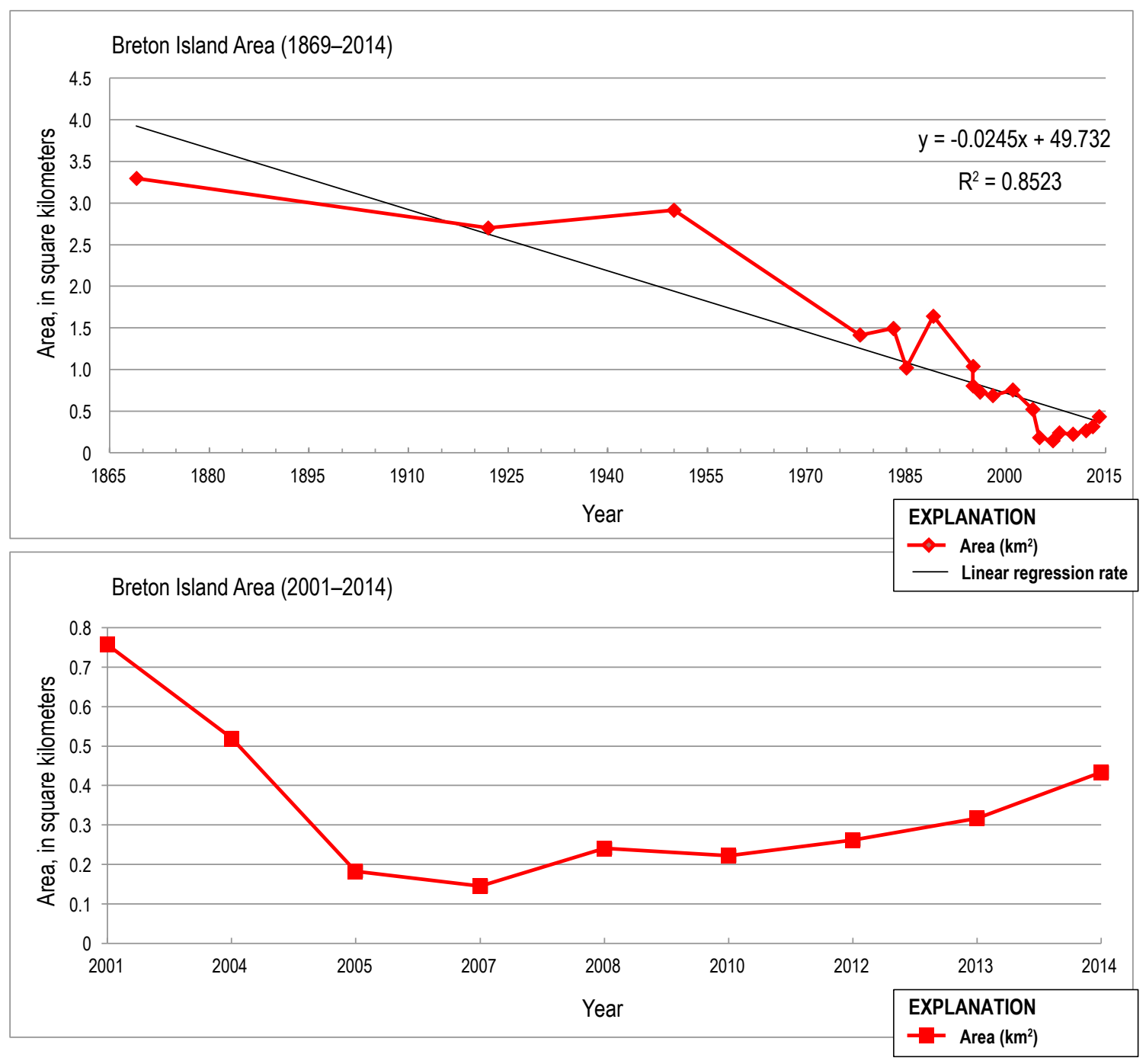

Figure 9. Graphs of island area calculated from available shoreline datasets of Breton Island. A, 1865-2014. B, 2001-2014.

Records for Breton Island indicate significant land area gains and losses, some associated with major storms. About one-half of the total land area was lost between 1950 and 1978 (table 4; fig. 9). During this period, five hurricanes and one tropical storms passed near, or directly over, Breton Island, notably tropical storm Brenda (1955) and Hurricanes Betsy (1965), and Camille (1969). Though all were strong storms, Hurricane Betsy passed more than $100 \mathrm{~km}$ to the west of Breton Island in 1965, whereas Hurricane Camille passed directly over Breton Island in 1969 as a category 4 storm. Field and aerial reconnaissance indicated Hurricane Camille was a significant destructive force and "almost leveled" the island (Wright and others, 1970). The lack of sufficient temporal data bracketing a single storm makes it difficult to quantify loss specifically because of the storm as opposed to contributing influences, such as the Mississippi River-Gulf Outlet shipping channel.

An increase in storm frequency during the past few decades (Fearnley and others, 2009) has accelerated land loss (fig. 10). Hurricanes Andrew (1992), Opal (1995), Georges (1998), and Ivan (2004) severely affected the island by eroding both beach sand and stabilizing marsh deposits, which are critical for maintaining shoreline position and island elevation. The storms segmented the island by breaching its narrow central part and developing a permanent inlet with an expanding ebb-tide delta (Creef and others, 2003; Michot and Wilson, 2004). 
Table 4. Shoreline length and island area for Breton Island.

[Date is the month and year given in the imagery metadata or Jan. 01 if unknown. Cells with a "--.-" denote years without a full shoreline dataset so no shoreline length could be calculated]

\begin{tabular}{llll}
\hline \multicolumn{1}{c}{ Year } & \multicolumn{1}{c}{ Date } & \multicolumn{1}{c}{$\begin{array}{c}\text { Shoreline } \\
\text { length }(\mathbf{k m})\end{array}$} & Area $\left(\mathbf{k m}^{2}\right)$ \\
\hline 1869 & Jan. 01 & 30.370 & 3.295 \\
${ }^{1} 1922$ & March 01 & 22.183 & 2.700 \\
${ }^{1} 1950$ & May 01 & 24.300 & 2.915 \\
${ }^{1} 1978$ & Jan. 01 & 34.426 & 1.410 \\
1983 & Nov. 17 & 16.641 & 1.498 \\
${ }^{2} 1985$ & Jan. 01 & --- & 1.020 \\
${ }^{1} 1989$ & Jan. 01 & --- & 1.640 \\
${ }^{2} 1995$ & April 01 & --- & 1.041 \\
${ }^{2} 1995$ & Nov. 01 & --- & 0.809 \\
${ }^{2} 1996$ & Nov. 01 & --- & 0.728 \\
1998 & Jan. 24 & 21.074 & 0.686 \\
2001 & Sept. 09 & 12.585 & 0.757 \\
2004 & Jan. 20 & 17.679 & 0.521 \\
2005 & Nov. 17 & 7.117 & 0.182 \\
2007 & Oct. 11 & 5.897 & 0.145 \\
2008 & Oct. 01 & 5.862 & 0.240 \\
2010 & May 10 & 6.694 & 0.222 \\
2012 & Oct. 20 & 6.527 & 0.262 \\
2013 & July 12 & 13.935 & 0.317 \\
2014 & Jan. 16 & 14.717 & 0.434 \\
\hline
\end{tabular}

${ }^{1}$ McBride and others, 1992

${ }^{2}$ Penland and others, 1997

${ }^{3}$ Value represents the foreshore shoreline length only.

The greatest effect of storms on island area happened during Hurricane Katrina (2005), which resulted in a land loss of 64 percent (from 0.52 to $0.18 \mathrm{~km}^{2}$ ). Aerial photographs (fig. 11) show that Breton Island was reduced to a temporary shoal after the storm. The island experienced significant sand loss, resulting in reduced island area and elevation (fig. 12). After Hurricane Katrina, Breton Island exhibited a slow rate of land loss until 2008 when the island began to recover. The absence of severe storms since Hurricane Katrina has allowed some island area recovery. The island has increased from the lowest point at $0.14 \mathrm{~km}^{2}$ in 2007 to $0.43 \mathrm{~km}^{2}$ in 2014 . The trajectory of Hurricanes Camille and Katrina placed the eastern eye wall, where the strongest wind speeds are recorded, directly over Breton Island. Storm trajectory likely plays a pivotal role in the overwash, erosion and reshaping of Breton Island.

In response to storm damage, four sand replenishment efforts were undertaken between 1993 and 2007 (fig. 10) by placing sand dredged from the Mississippi River-Gulf Outlet shipping channel to a location adjacent to the island with the intent of supplying sediment to the shoreline through littoral transport (Creef and others, 2003; Thomson and others, 2010). Estimated volumes of sand placement were 1.2x106 m3 (1993), 3.7x106 m3 (1999), 1.5x106 m3 (2001), and 3.1x106 m3 (2005). The sand placements were sacrificial in that they were not engineered for island restoration (for example, dunes). 


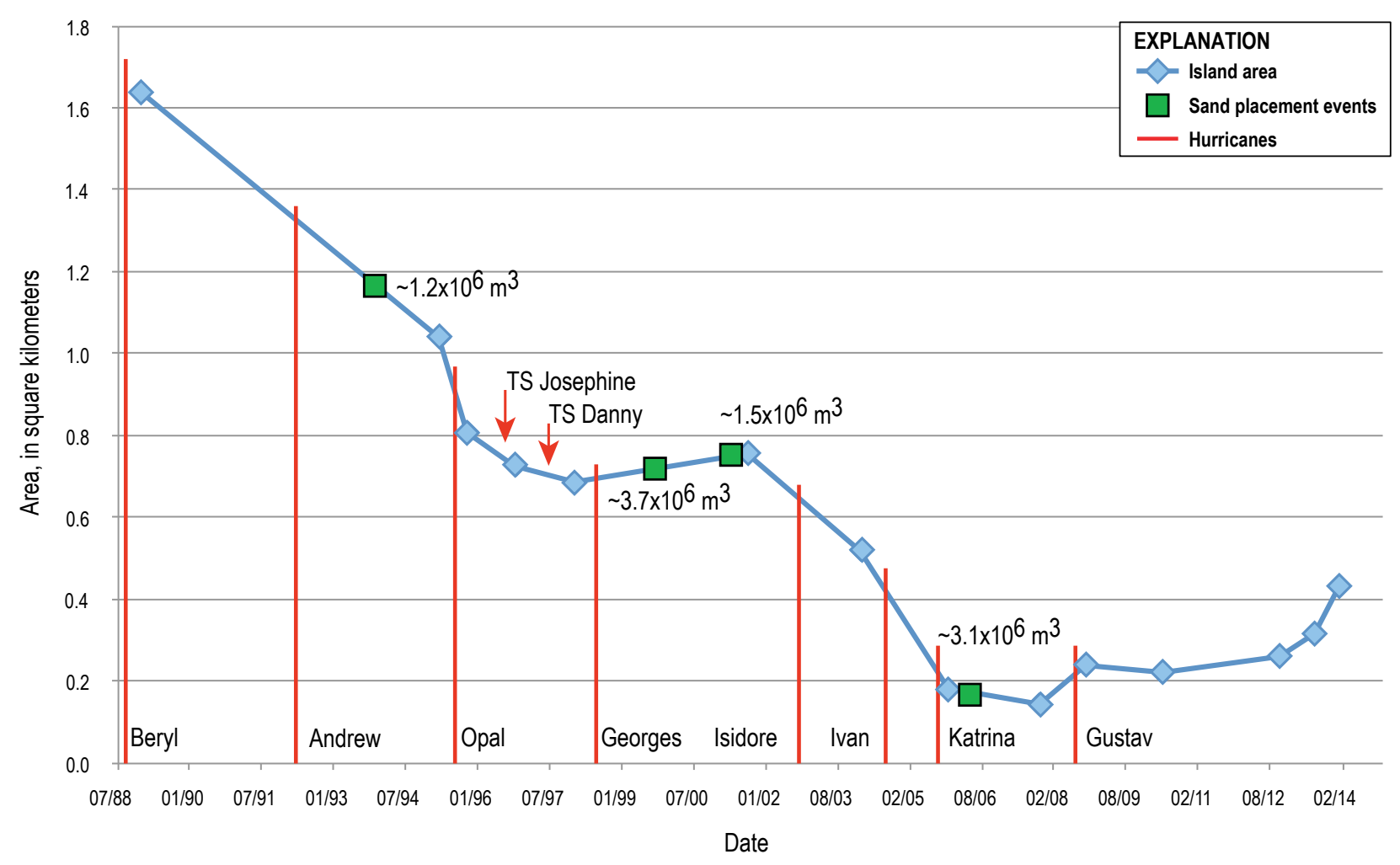

Figure 10. Graph of recent (1988 to 2014) island area change, storms, and sand placement events.

The sand replenishments increased island area, but subsequent storms quickly removed the added sediments. This is most notable with two sand placements after Hurricane Georges, which visibly expanded the shoreface (fig. 11). Island area increased by 10 percent until Hurricane Isidore affected the island in 2002, removing the supplied sand and reducing island area by 45 percent (fig. 10).

Breton Island exhibits a mixed history of erosional events. Slow decreases in area have been punctuated by acute weather events with severe effects to area. Breton Island has also exhibited signs of recovery during static periods with no storms (fig. 9). Between 1985 and 1989, island area increased by $0.62 \mathrm{~km}^{2}$, and during 2010 to 2014, there was a growth of $0.21 \mathrm{~km}^{2}$. The most recent accretion can be attributed to a lack of severe storms near Louisiana since the end of the 2008 hurricane season. Island geomorphic trends are connected to major storm events, which result in a reduction in island area and change in shape. This is followed by slow sand accretion and recovery given available offshore sand. In cases where the eastern eye wall of the storm passed directly over Breton Island, there was a more significant reduction in its area.

\section{Shoreline Change Results}

Shoreline change analysis of barrier islands can provide crucial information on sediment budget, island migration, the rates of shoreline change, and provides clues to barrier island resilience to future storms and sea-level rise. The rate of shoreline change can vary with time because of extreme events, changes in sediment flux, and accelerating sea-level rise; therefore, the analysis was completed for both long-term (1869-2014) and short-term (early to pre-Mississippi River-Gulf Outlet (1869-1949), recent past (1950-2014), pre/post-Hurricane Katrina (2004-2005), and post-Hurricane Katrina (2005-14) periods. 

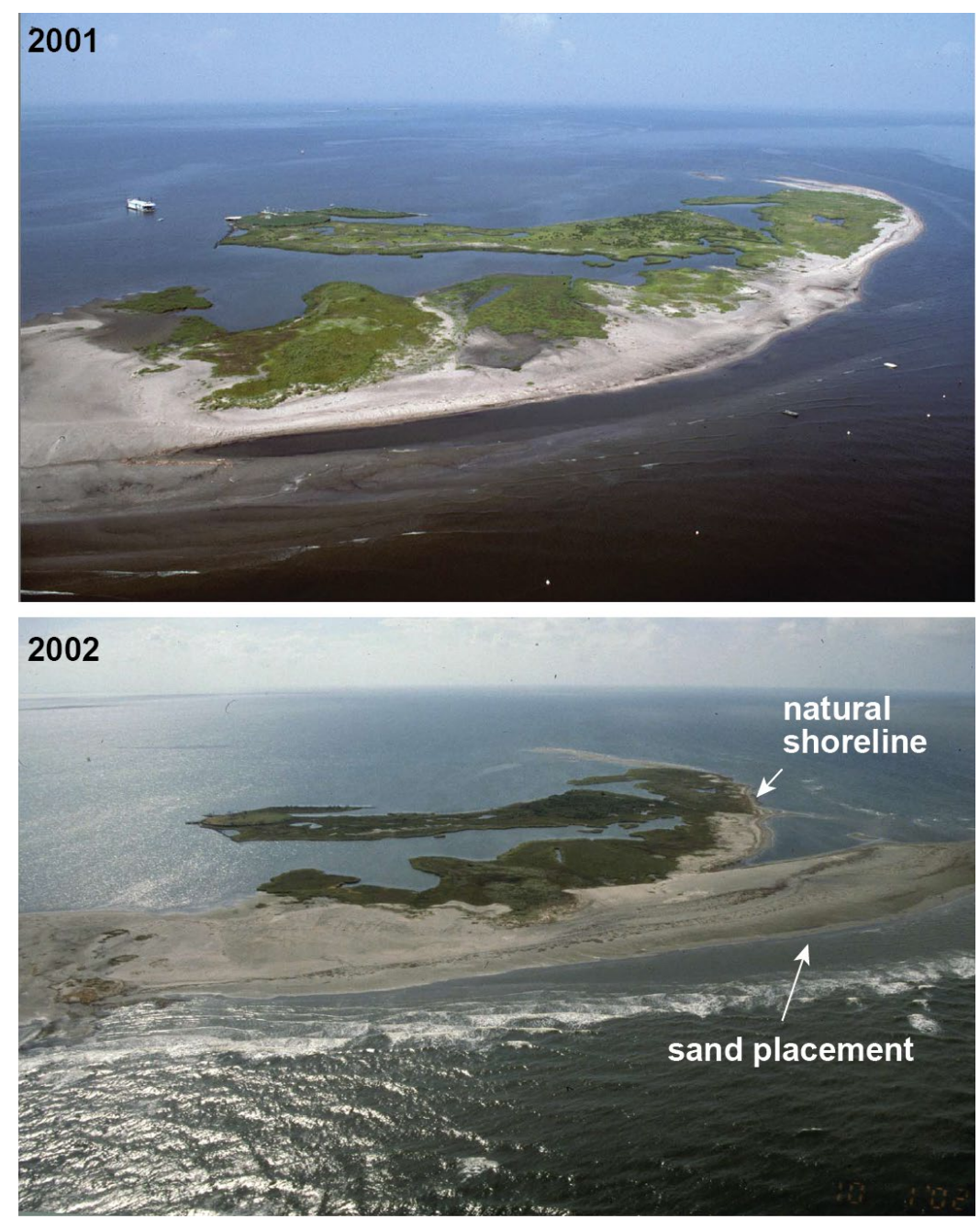

Figure 11. Oblique aerial imagery of Breton Island before (2001) and after (2002) a sand placement event (shown in fig. 10). Sand was placed within the normal wave zone of the island platform with the intent of it redistributing across the shoreface through littoral transport (Westphal and others, 2009).

\section{Long-Term (1869-2014) Shoreline Change}

The long-term (1869-2014) shoreline change included all available shoreline data from 1869 to 2014, representing a total of 14 dated shoreline positions. For the long-term shoreline change analysis, 199 out of 211 transects were used to calculate the average statistics. A total of 12 transects were not included because of insufficient shorelines, which were insufficient because they were within the breach or at northern or southern parts of the island. Many transects had null values for LRR, LR2, and WLR but were left in the analyses because they provide useful NSM, EPR, and SCE results. The foreshore of Breton Island experienced a NSM of $-695 \pm 44 \mathrm{~m}$ from 1869 to 2014, which equates to a landward erosion rate of $-5 \pm 0.3$ meters per year $(\mathrm{m} / \mathrm{yr})\left(R^{2}=0.74\right)$ (table 3$)$. The overall distance of SCE, was about $846 \pm 36 \mathrm{~m}$, which is greater than the net shoreline movement. The SCE is reported as a positive value because it represents the greatest distance between the closest and farthest shoreline from the baseline. The average WLR of $-7 \pm 0.4 \mathrm{~m} / \mathrm{yr}\left(R^{2}=0.73\right)$, which gives more weight to more confident shorelines data, suggests potentially higher rates of change. The three rate-of-change statistics (EPR, LRR, and WLR) are fairly consistent, suggesting that Breton Island is experiencing an overall rate of erosion of around 5 to $7 \mathrm{~m} / \mathrm{yr}$. 
Although general trends can be characterized by the summarized statistics, the variability in shoreline change can be viewed in more detail by looking at the data's spatial distribution. Shorelines were clipped using the SCE to display the distance between the closest and farthest shoreline from the baseline in figure 13. In figure 14, the SCE clipped transects were used to create a map depicting the shoreline change range rate (EPR) by transect and shows the spatial variation of shoreline change. This method for displaying the SCE was chosen because it was the method outlined in the DSAS manual. The northern part of the island is experiencing the highest erosion rates (between 5 and $14 \mathrm{~m} / \mathrm{yr}$ ). The
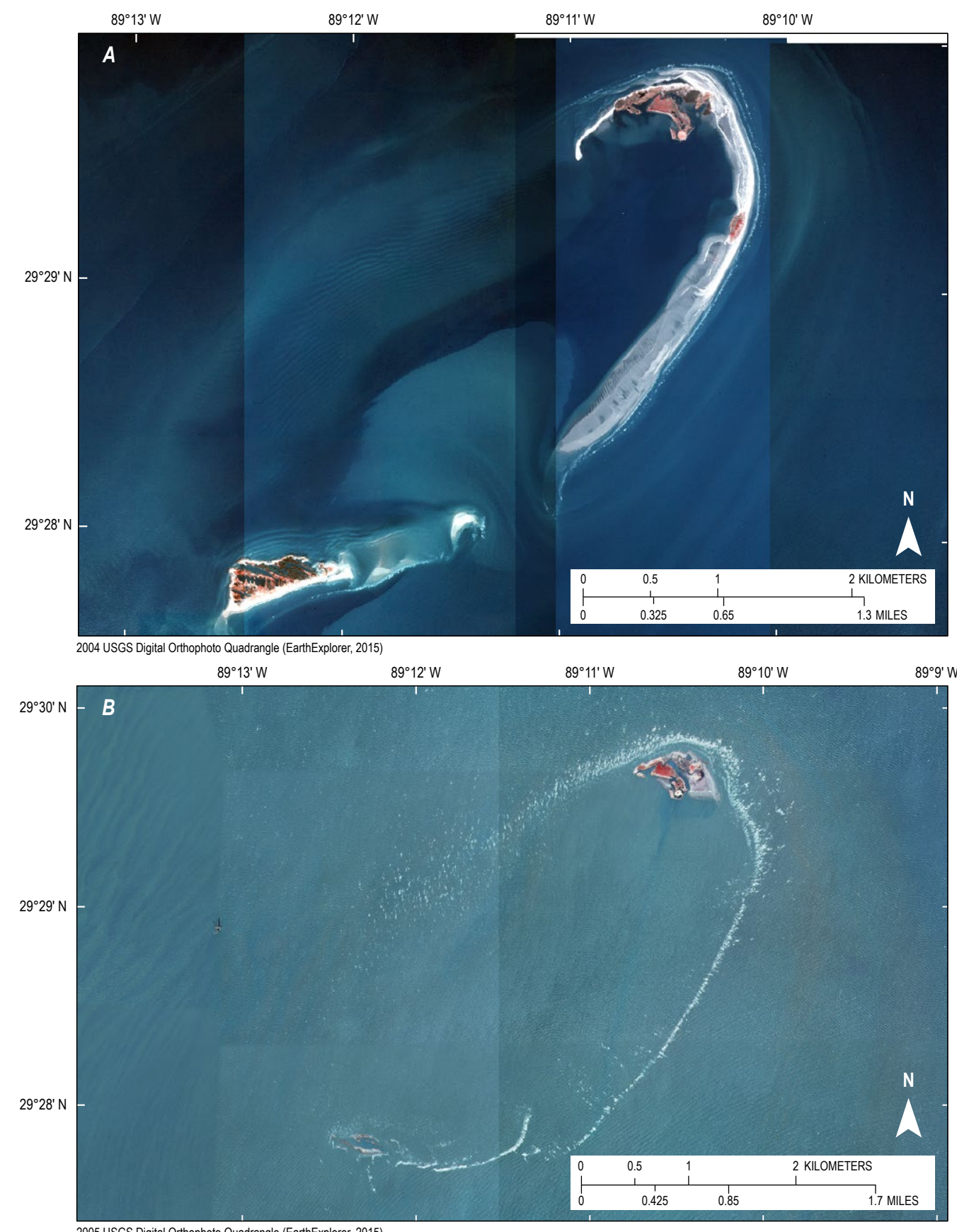

Figure 12. Comparison of pre- and post-Hurricane Katrina aerial images. A, pre-Hurricane Katrina (2004). B, post-Hurricane Katrina (2005). After Hurricane Katrina, Breton Island was largely submerged and suffered an extensive amount of sediment removal. 
southern shoreline, which is separated from the northern shoreline by a breach, has accreted in some cases by as much as $6 \mathrm{~m} / \mathrm{yr}$.

Several previous reports have examined long-term shoreline change for Breton Island (Penland and Sallender, 1992; Penland and others, 1997; Fearnley and others, 2009; Martinez and others, 2009). Results reported here likely differ because of the addition of recent shoreline data, which may alter long-term trends, a difference in the analysis method because of updates in geospatial technology, or both. The most recent analysis (Martinez and others, 2009), which followed a similar methodology, suggests a higher rate of shoreline erosion; therefore, to check the analysis, the same data (baseline, transects, and shorelines) from Martinez and others (2009) were analyzed, and the results were similar. This comparison suggests that this report, with the addition of 7 shoreline datasets, determines the long-term shoreline erosion rate has decreased. These data draw attention to the influence of the temporal range and resolution in shoreline change analysis and the importance of long-term trends in barrier island development.

\section{Short-Term Shoreline Change}

The short-term shoreline change analysis included four analysis windows: pre-1950 (18691950); post-1950 (1950-present); pre/post-Hurricane Katrina (2004-5); and post-Hurricane Katrina (2005-present).

The pre-1950 analysis consisted of three T-sheet shorelines from 1869 and 1950 and used 192 out of the 211 transects. The average shoreline erosion was $-381 \pm 30.3 \mathrm{~m}$, equivalent to a rate of $-5 \pm 0.4$ $\mathrm{m} / \mathrm{yr}\left(R^{2}=0.71\right)$. The LLR and WLR were not calculated at many transects because of fewer than three shorelines present, which is the minimum required for DSAS to calculate the linear regression (Thieler and others, 2009).
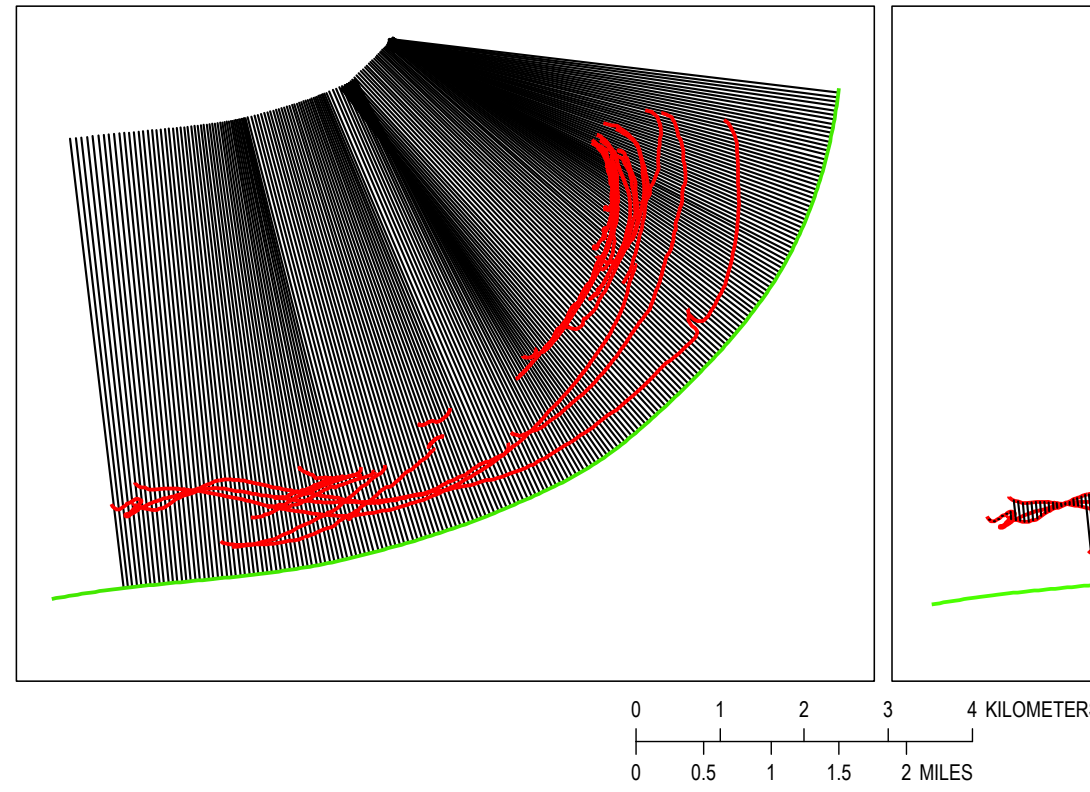

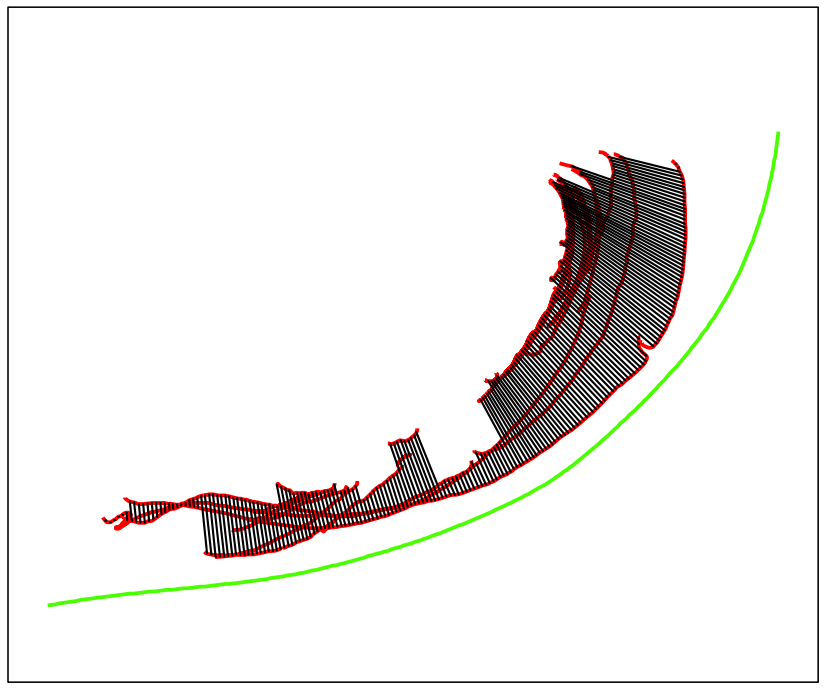

EXPLANATION

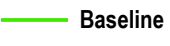

Breton Island 1869-2014 Foreshore Shorelines

Breton Island Transects

Figure 13. Transects before and after clipping to the shoreline change extent for all foreshore shorelines (1869-2014). The shoreline change extent represents the distance between the farthest and the closest foreshore shoreline from the baseline. $A$, transects before clipping to the shoreline change extent. $B$, transects after clipping to the shoreline change extent. 
The post-1950 analysis was completed to determine if there has been a significant effect on Breton Island shoreline change since the occurrence of significant anthropogenic shoreline modification. 1950 was chosen as the starting point because of the construction of the Mississippi River-Gulf Outlet shipping channel adjacent to the island during that period (Penland and others, 1997). Maintenance of the shipping channel included periodic removal of sediment and disposal offshore, restricting the natural supply of sand to the island. For this analysis, 146 out of the 211 transects were used to calculate the statistics. The NSM from 1950 to 2014 showed a landward erosion distance of $-364 \pm 22 \mathrm{~m}$. The LRR for the post-1950 was calculated at $-7 \pm 0.6 \mathrm{~m} / \mathrm{yr}(R 2=0.78)$. The WLR shows an erosion rate of $-11 \pm 0.5 \mathrm{~m} / \mathrm{yr}$. Taking into account all rates of change metrics for post-1950, there was an erosion rate between 6 and $11 \mathrm{~m} / \mathrm{yr}$ from the 1950 to 2014. Comparisons of pre- and post-1950 data indicate an increase in the rate of erosion of $2 \mathrm{~m} / \mathrm{yr}$. These changes are within the error of the calculated values and do not indicate a significant change in island transgression between the periods, although island area changed dramatically.

Short-term catastrophic change can be characterized by analyzing the period before and after Hurricane Katrina (2004-5). The pre-storm shoreline for Hurricane Katrina was created from imagery collected on January 20, 2004 (table 2). Hurricane Katrina passed through the Breton Island area on August 29, 2005, as a category 4 storm that weakened to a category 3 as it made landfall west of the island (table 1; fig. 3). The post-storm shoreline was created from imagery collected on November 17, 2005 (fig. 10). After removing transects with null and zero values, only 21 out of the 211 transects were

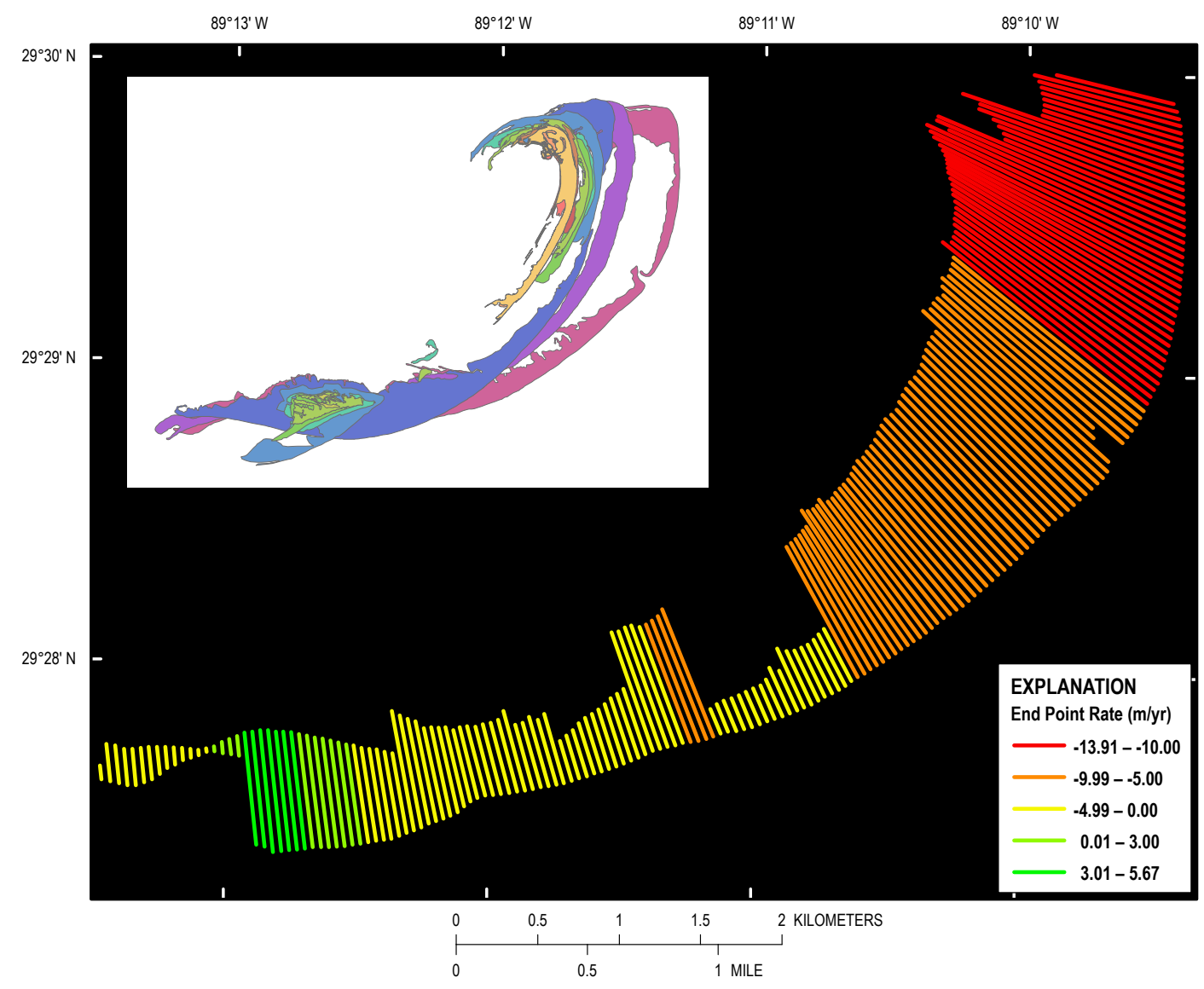

Figure 14. Map of shoreline change extent clipped transects color-coded by the end point rate for 1869-2014. Negative values represent erosion, and positive values represent accretion. 
available for summary statistics. For this analysis, LRR and WLR could not be calculated because only two shorelines were used. The foreshore NSM caused by Hurricane Katrina was $130 \mathrm{~m}$ of landward transgression and an erosion rate of $72 \mathrm{~m} / \mathrm{yr}$, which is consistent with data collected at the Chandeleur Islands (Sallenger and others, 2009). Before Hurricane Katrina, Breton Island had a combined foreshore and backshore shoreline length of $17.7 \mathrm{~km}$. After the storm passed, the shoreline length was reduced to $7.1 \mathrm{~km}$ for a total loss of $10.6 \mathrm{~km}$ of shoreline. The data indicate that immediate shoreline erosion from storms can be dramatic: on the order of ten times the erosion rate of long-term shoreline trends.

Hurricane Katrina caused significant erosion at Breton Island that was characterized in the BICM Project (Fearnley and others, 2009; Martinez and others, 2009). The previous reports (Penland and Sallender, 1992; Penland and others, 1997; Fearnley and others, 2009; Martinez and others, 2009) have been significantly augmented by this current study, with numerous datasets, primarily 7 new shorelines, collected after Hurricane Katrina that provide additional information on barrier island post-storm recovery (table 2). Since Hurricane Katrina, the short-term (2005 to 2014) NSM for Breton Island shows a seaward movement of $5 \pm 6.3 \mathrm{~m}$ and an average accretion rate of $29 \pm 5.1 \mathrm{~m} / \mathrm{yr}$ (table 3 ). The average SCE for 2005 to 2014 was $79 \pm 6.3 \mathrm{~m}$. The LRR and WLR for the post-Hurricane Katrina analysis was an erosion rate of $9 \pm 1.6 \mathrm{~m} / \mathrm{yr}\left(R^{2}=0.31\right)$ and $7 \pm 3.4 \mathrm{~m} / \mathrm{yr}$, respectively. Both regression statistics indicate a trend toward erosion; however, specific areas of the Breton Island foreshore both eroded and accreted, with shoreline change rates up to $11 \mathrm{~m} / \mathrm{yr}$. Accretion and erosion was evenly spread throughout most of Breton Island and did not show areas with extreme erosion or accretion. This, along with the positive EPR and the increase in island area reported in an earlier section, indicates a general trend of recovery and accretion after 2 years of decline after Hurricane Katrina.

Also, episodic events, such as hurricanes, have a dramatic influence on short-term shoreline erosion (fig. 10). In addition, barrier islands experience recovery periods following a storm, as sediment is moved and aggregated from post-storm waves. It is these short-term trends that are most misunderstood and warrant frequent data collection, including post-storm monitoring of shorelines and island elevation.

\section{Elevation and Volume Analysis}

Lidar was acquired for Breton Island on four dates during the years of 2001, 2007, 2013, and 2014, providing elevation data for the island. Comparing the lidar elevation datasets provides data for measurable change analysis. During 2001, the north and south islands had land above the water level and were surveyed. All successive lidar surveys were collected for the north island only because the south island was largely submerged in 2005 during Hurricane Katrina. As mentioned, only the values above the MHW level were used to complete the elevation and volume change analysis to remove submerged areas. When displaying the elevation change results in figure 15, the lidar data was used "as is" to include as much elevation change data as possible.

Sediment volumes were produced for 2001, 2007, 2013, and 2014 (table 5). The 2001 northern part of Breton Island, pre-Hurricane Katrina, shows a volume of $1.86923 \times 10^{5}$ cubic meters $\left(\mathrm{m}^{3}\right)$ of sediment above the MHW. In 2007, post-Hurricane Katrina, the sediment volume was $3.61 \times 10^{4} \mathrm{~m}^{3}$, an 81-percent reduction from 2001. After 2007, Breton Island volume increased by more than 100 percent in about 6 years during a relatively storm-free period. Breton Island continues to increase in volume, with a 65-percent increase in 2014 from 2013. Oblique aerial photographs collected by the USGS were used as confirmation that the southern part of Breton Island was submerged in 2012 and 2013 (fig. 16).

Because island area was different for each island volume estimate, the volume per unit area was

calculated and provides a normalized statistic with which to compare volume loss while controlling for 

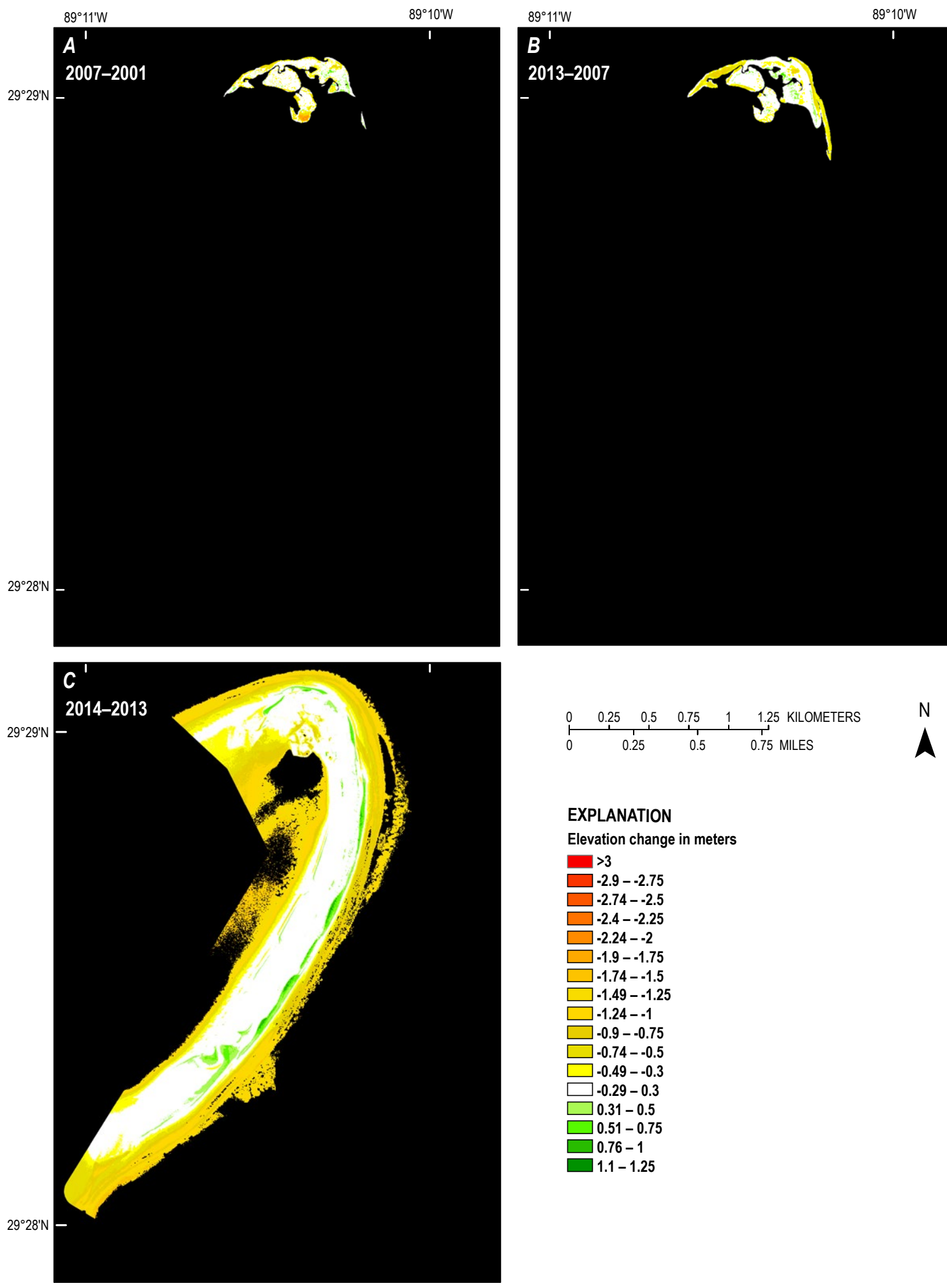

\section{EXPLANATION}

Elevation change in meters

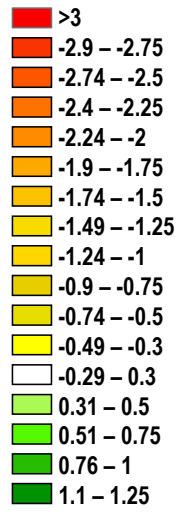

Figure 15. Maps of light and detection ranging elevation change. A, between 2007 and 2001. B, between 2013 and 2007. C, between 2014 and 2013. 
Table 5. Sediment volume, average elevation, and maximum elevation above the mean high water ( 0.23 meter) from light and detection ranging data collected in 2001, 2007, 2013, and 2014..

[Values represent all of Breton Island unless noted otherwise]

\begin{tabular}{lccccc}
\hline & $\mathbf{2 0 0 1}$ (northern) & $\mathbf{2 0 0 1}$ (southern) & $\mathbf{2 0 0 7}$ & $\mathbf{2 0 1 3}$ & $\mathbf{2 0 1 4}$ \\
\cline { 2 - 6 } Volume $\left(\mathrm{m}^{3}\right)$ & 186,923 & 90,972 & 36,089 & 77,941 & 128,691 \\
Average elevation $(\mathrm{m})$ & 0.61 & 0.57 & 0.48 & 0.47 & 0.52 \\
Max elevation $(\mathrm{m})$ & 3.24 & 2.40 & 1.90 & 1.97 & 2.11 \\
\hline
\end{tabular}

${ }^{1}$ Values represent only the northern part of Breton Island because the southern part was submerged during these years.
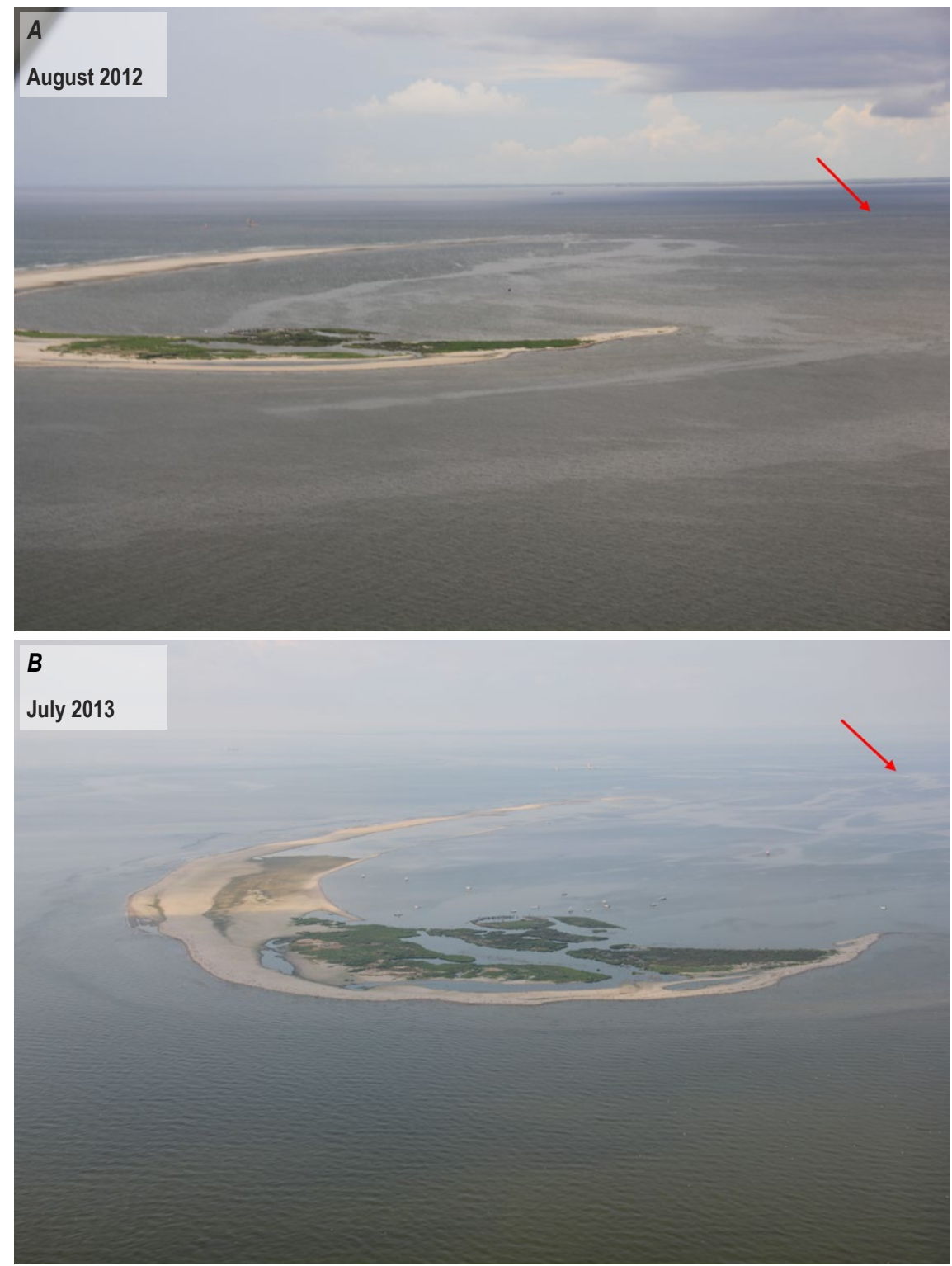

Figure 16. Oblique aerial images from August 2012 (top) and July 2013 (bottom) showing that the southern portion of Breton Island is submerged (red arrows). Images from Morgan and Westphal (2014a, 2014b). 
loss in island area. The volume per unit area of the northern part of Breton Island has decreased from 3.9 cubic meters per square kilometers $\left(\mathrm{m}^{3} / \mathrm{km}^{2}\right)$ in 2001 to $2.4 \mathrm{~m}^{3} / \mathrm{km}^{2}$ in 2013 . It increased in 2014 to $3.0 \mathrm{~m}^{3} / \mathrm{km}^{2}$. Although the volume and size of Breton Island increased from 2007 to 2013 after Hurricane Katrina, it was not until 2014 that island volume per unit area showed a marked increase. While these comparisons are for the northern part only, it is important to note the submergence of the southern island resulted in a $9.0 \times 10^{4} \mathrm{~m}^{3}$ loss in above MHW sediment volume.

Elevation change maps provide information on the location of elevation loss or gain within the island boundaries. Volume loss in submerged locations was not possible. The 2007-2001 elevation change map (fig. 15) shows that there was minimal elevation change with some loss near the former Kerr-McGee infrastructure. The average and maximum elevations were reduced by 0.13 and $1.34 \mathrm{~m}$, respectively (table 5). Although there was significant loss of island area, the elevation of what remained of the island was relatively stable.

The 20013-2007 lidar comparison suggests that there was little elevation change within the vegetated part of the island (fig. 15). During this period, the beaches experienced a slight loss in elevation, whereas there were slight increases in elevation scattered throughout the island interior. The average elevation increased by $0.07 \mathrm{~m}$, whereas the maximum elevation decreased by $0.01 \mathrm{~m}$ (table 5).

The elevation comparison using the most recent lidar data (2014-2013) shows that Breton Islands' position and elevation has remained relatively constant (average elevation gain of $0.05 \mathrm{~m}$ and maximum elevation gain of $0.14 \mathrm{~m}$ ) (table 5; fig. 15). Though there was mostly no change in the interior of the island, there was an increase in elevation on the seaward side of the island along the beach that extends from the northern-most part to the southern-most part. Near the northern-most part of the island, a small area of wetland area experienced elevation loss.

\section{Conclusion}

The monitoring of barrier island shoreline and area change with time is important to understanding island evolution, response to storm effect and sea-level rise, and island vulnerability to future oceanographic and anthropogenic influences. This report expands previous shoreline change studies of Breton Island by incorporating new and additional historic datasets. The island has responded to a complex chronology of natural and human processes that include numerous storm effects, sea-level rise, sacrificial replenishment of shoreface sands, and disruption of littoral processes through the maintenance dredging of the Mississippi River-Gulf Outlet ship channel. This study revealed that the long-term historic (1860-1950) change was a significant net shoreline retreat of more than $5 \mathrm{~m} / \mathrm{yr}$, and a reduction in island area of 11 percent. This trend represents the gradual decline in island structure in response to relative sea-level rise and a general decrease in sediment supply. Gradual island change was punctuated by rapid land loss during storms. The response of the island to these natural processes was similar to those observed along the Chandeleur Islands to the north. Anthropogenic influences on island evolution began following the completion of the Mississippi River-Gulf Outlet ship channel in 1968. Between 1950 and 1978, shoreline retreat increased to $6.9 \mathrm{~m} / \mathrm{yr}$, and the island lost one-half of its pre-Mississippi RiverGulf Outlet area indicating a disruption in sediment supply to the island by restricting the predominant north-south littoral transport. It should be noted that within the same period Hurricane Camille made landfall (1969), severely affecting the island. Several efforts to supply sediment to the island platform through beneficial-use dredging happened in the following years, increasing island area. These replenishment efforts consisted of sand placements adjacent to the island shoreline and were not engineered coastal renourishments (for example, construction of dunes, shoreface, and back-barrier marsh); thus, 
during storms, the sand deposits were quickly redistributed and removed from the system (for example, Hurricane Isidore).

The frequency of hurricanes and tropical storms passing within $150 \mathrm{~km}$ to the island since Hurricane Camille (1968-2008) was the highest compared to similar periods during recorded history. Photo imagery of the island after Hurricane Katrina shows extensive removal of sand from the barrier island platform and demonstrates how rapid change happens. The data indicate that erosion from storms can be 10 times the erosion rate of long-term trends. Increased storm impacts, coupled with the reduction in island area after construction of the Mississippi River-Gulf Outlet, has reduced Breton Island to near shoal conditions; however, since Hurricane Gustav in 2008, no storms of significance have passed by and island area has slowly increased. What has been missing in studies to date is accurate measurement of island recovery in the years between storm events. Analysis of shoreline change after Hurricane Katrina indicates that after 2 years of continued decline and without subsequent interruption by storms, the island began a period of recovery. Short-term trends are poorly understood because of infrequent, intermittent shoreline mapping intervals. This study demonstrates the ability to monitor highly-dynamic barrier island systems using various georeferenced datasets and the importance of frequent data collection, especially surrounding storm and anthropogenic effects.

\section{References Cited}

Anders, F.J., and Byrnes, M.R., 1991, Accuracy of shoreline change rates as determined from maps and aerial photographs: Shore and Beach, v. 59, no. 1, p. 17-26.

Andrew, 2012, National Oceanic and Atmospheric Administration, Hurricane Andrew information web page, accessed October 01, 2015, at http://www.srh.noaa.gov/mfl/?n=andrew.

Creef, E.D., Mathies, L.G., and Hennington, S.M., 2003, Breton Island Restoration Project, in Garbaciak, Sephen, Jr., ed., Dredging '02 — Key technologies for global prosperity: American Society of Civil Engineers, 5 p. [Also available at http://dx.doi.org/10.1061/40680(2003)13.]

Crowell, Mark, Leatherman, S.P., and Buckley, M.K., 1991, Historical shoreline change_Error analysis and mapping accuracy: Journal of Coastal Research, v. 7, no. 3, p. 839-852.

[Also available at http://www.jstor.org/stable/4297899.]

Curtiss, David, and Pierce, A.R., in press, Evaluation of wintering waterbird habitats on Louisiana barrier islands: Journal of Coastal Research, accessed March 10, 2016], at http://dx.doi.org/10.2112/JCOASTRES-D-14-00141.1.

EarthExplorer, 2015, U.S. Geological Survey, Remote sensing data information and download web page, accessed October 01, 2015, at http://earthexplorer.usgs.gov/.

Environmental Systems Research Institute (ESRI), 2015, ArcGIS (ver. 10.3.1) [Computer Software]: Software for geographic mapping, manipulation, and data storage. Web page, accessed March 01, 2016, at http://www.esri.com/software/arcgis.

Fearnley, Sarah; Miner, Michael; Kulp, Mark; Bohling, Carl; Martinez, Luis; and Penland, Shea, 2009, Hurricane impact and recovery shoreline change analysis and historical island configuration-1700s to 2005, chap. A of Lavoie, Dawn, ed., Sand resources, regional geology, and coastal processes of the Chandeleur Islands coastal system-An evaluation of the Breton National Wildlife Refuge: U.S. Geological Survey Scientific Investigations Report 2009-5252, p. 7-26.

[Also available at http://pubs.usgs.gov/sir/2009/5252/.] 
Fritz, H.M.; Blount, Chris; Sokoloski, Robert; Singleton, Justin; Fuggle, Andrew; McAdoo, B.G.; Moore, Andrew; Grass, Chad; and Tate, Banks, 2007, Hurricane Katrina storm surge distribution and field observations on the Mississippi Barrier Islands: Estuarine, Coastal and Shelf Science, v. 74, no. 1, p. 12-20. [Also available at http://dx.doi.org/10.1016/j.ecss.2007.03.015.]

Guy, K.K., and Plant, N.G., 2014, Topographic lidar survey of Dauphin Island, Alabama and Chandeleur, Stake, Grand Gosier and Breton Islands, Louisiana, July 12-14, 2013: U.S. Geological Survey Data Series 838, 1 p., [Also available at http://dx.doi.org/10.3133/ds838].

Hapke, C.J., Himmelstoss, E.A., Kratzmann, M.G., List, J.H., and Thieler, E.R., 2010, National assessment of shoreline change-Historical shoreline change along the New England and Mid-Atlantic coasts: U.S. Geological Survey Open-File Report 2010-1118, 57 p.

[Also available at http://pubs.usgs.gov/of/2010/1118/.]

Houston, S.H., Shaffer, W.A., Powell, M.D., and Chen, Jye, 1999, Comparisons of HRD and SLOSH surface wind fields in hurricanes - Implications for storm surge modeling: Weather and Forecasting, v. 14, no. 5, p. 671-686. [Also available at http://www.nws.noaa.gov/mdl/pubs/Documents/Papers/ Shaffer1999ComparisonOfHRD.pdf.]

Hoyt, J.H., 1967, Barrier island formation: Geological Society of America Bulletin, v. 78, no. 9 , p. 1125-1136. [Also available at http://dx.doi.org/10.1130/0016-7606(1967)78[1125:BIF]2.0.CO;2.]

Isidore, 2003, National Oceanic and Atmospheric Administration, Hurricane Isidore information web page, accessed October 01, 2015, at http://www.nhc.noaa.gov/data/tcr/AL102002_Isidore.pdf.

Kahn, J.H., and Roberts, H.H., 1982, Variations in storm response along a microtidal transgressive barrier-island arc: Sedimentary Geology, v. 33, no. 2, p. 129-146. [Also available at http://dx.doi.org/10.1016/0037-0738(82)90046-X.]

Kindinger, J.L., Buster, N.A., Flocks, J.G., Bernier, J.C., and Kulp, M.A., 2013, Louisiana Barrier Island Comprehensive Monitoring (BICM) Program summary report—Data and analyses 2006 through 2010: U.S. Geological Survey Open-File Report 2013-1083, 86 p.

[Also available at http://pubs.usgs.gov/of/2013/1083/.]

Knabb, R.D., Rhome, J.R., and Brown, D.P., 2005, Tropical cyclone report-Hurricane Katrina, 23-30 August 2005: National Hurricane Center, 43 p.

[Also available at http://www.nhc.noaa.gov/data/tcr/AL122005_Katrina.pdf.]

Lavoie, Dawn, 2009, Executive summary, in Lavoie, Dawn, ed., Sand resources, regional geology, and coastal processes of the Chandeleur Islands coastal system-An evaluation of the Breton National Wildlife Refuge: U.S. Geological Survey Scientific Investigations Report 2009-5252, p. 1-6. [Also available at http://pubs.usgs.gov/sir/2009/5252/.]

Lavoie, Dawn, Flocks, J.G., Kindinger, J.L., Sallenger, A.H., Jr., and Twichell, D.C., 2010, Effects of building a sand barrier berm to mitigate the effects of the Deepwater Horizon oil spill on Louisiana marshes: U.S. Geological Survey Open-File Report 2010-1108, 7 p.

[Also available at http://pubs.usgs.gov/of/2010/1108/.]

Martinez, Luis; O’Brien, Sean; Bethel, Matt; Penland, Shea; and Kulp, Mark, 2009, Louisiana Barrier Island Comprehensive Monitoring Program (BICM) volume 2-Shoreline changes and barrier island land loss 1800's-2005: New Orleans, La., University of New Orleans, Pontchartrain Institute for Environmental Sciences, 32 p. [Also available at http://lacoast.gov/reports/project/3890772 1.pdf.] 
McBride, R.A., Penland, Shea, Hiland, M.W., Williams, S.J., Westphal, K.A., Jaffe, B.E., and Sallenger, A.H., Jr., 1992, Analysis of barrier shoreline change in Louisiana from 1853 to 1989, chap. 4 of Williams, S.J., Penland, Shea, and Sallenger, A.H., Jr., eds., Atlas of shoreline changes in Louisiana from 1853 to 1989-Louisiana Barrier Island Erosion Study: U.S. Geological Survey Miscellaneous Investigations Series I-2150-A, p. 36-97. [Also available at http://pubs.usgs.gov/imap/2150a/report.pdf.]

McBride, R.A., and Byrnes, M.R., 1997, Regional variations in shore response along barrier island systems of the Mississippi River delta plain-Historical change and future prediction: Journal of Coastal Research, v. 13, no. 3, p. 628-655. [Also available at http://www.jstor.org/stable/4298660.]

Michot, T.C., and Wilson, Scott, 2004, Post-hurricane Ivan survey of Chandeleur Islands, LouisianaAerial survey date September 17-18, 2004: U.S. Geological Survey, National Wetlands Research Center. [Also available at http://www.nwrc.usgs.gov/topics/hurricane/ivan/postivanphotos.htm.]

Moore, L.J., 2000, Shoreline mapping techniques: Journal of Coastal Research, v. 16, no. 1, p. 111-124. [Also available at http://www.jstor.org/stable/4300016.]

Morgan, J.P., and Larimore, P.B., 1957, Changes in the Louisiana shoreline: Changes, v. 7, p. 303-310.

Morgan, K.L.M., Krohn, M.D., Doran, Kara, and Guy, K.K., 2013, Baseline coastal oblique aerial photographs collected from Pensacola, Florida, to Breton Islands, Louisiana, February 7, 2012: U.S. Geological Survey Data Series 799. [Also available at http://pubs.usgs.gov/ds/0799/.]

Morgan, K.L.M., and Westphal, K.A., 2014a, Baseline coastal oblique aerial photographs collected from Breton Island, Louisiana, to the Alabama-Florida border, July 13, 2013: U.S. Geological Survey Data Series 857. [Also available at http://dx.doi.org/10.3133/ds857.]

Morgan, K.L.M., and Westphal, K.A., 2014b, Baseline coastal oblique aerial photographs collected from Dauphin Island, Alabama, to Breton Island, Louisiana, August 8, 2012: U.S. Geological Survey Data Series 860. [Also available at http://dx.doi.org/10.3133/ds860.]

Morton, R.A., 1991, Accurate shoreline mapping - Past, present, and future: American Society of Civil Engineers, Coastal Sediments, v. 1, p. 997-1010.

Morton, R.A., Miller, T.L., and Moore, L.J., 2004, National assessment of shoreline change_Part 1, historical shoreline changes and associated coastal land loss along the U.S. Gulf of Mexico: U.S. Geological Survey Open-file Report 2004-1043, 45 p.

[Also available at http://pubs.usgs.gov/of/2004/1043/.]

National Geodetic Survey, 2014, VDatum (ver. 3.4) [Computer Software]: National Oceanic and Atmospheric Administration, Vertical Datum Transformation Web page, accessed October 01, 2015, at http://vdatum.noaa.gov/.

Opal, 2015, National Oceanic and Atmospheric Administration, Hurricane Opal information web page, accessed November 15, 2015, at http://www.srh.noaa.gov/mob/?n=opal.

Otvos, E.G., and Carter, G.A., 2008, Hurricane degradation-barrier development cycles, northeastern Gulf of Mexico-Landform evolution and island chain history: Journal of Coastal Research, v. 24, no. 2, p. 463-478. [Also available at http://dx.doi.org/10.2112/06-0820.1.]

Penland, Shea; Boyd, Ron; Nummedal, Dag; and Roberts, Harry, 1981, Deltaic barrier development on the Louisiana coast: Transactions of the Gulf Coast Association of Geological Societies, v. 31, p. 471-476. [Also available at http://archives.datapages.com/data/gcags/data/031/031001/0471.htm.] 
Penland, Shea, and Boyd, Ron, 1981, Shoreline changes on the Louisiana barrier coast: Institute of Electrical and Electronics Engineers, Oceans 81, p. 209-219.

[Also available at http://dx.doi.org/10.1109/OCEANS.1981.1151652.]

Penland, Shea, Suter, J.R., and Boyd, Ron, 1985, Barrier island arcs along abandoned Mississippi River deltas: Marine Geology, v. 63, no. 1-4, p. 197-233.

Penland, Shea, Boyd, Ron, and Suter, J.R., 1988, Transgressive depositional systems of the Mississippi delta plain: a model for barrier shoreline and shelf sand development: Journal of Sedimentary Research, v. 58, no. 6, p. 932-949. [Also available at http://archives.datapages.com/data/sepm/journals/ v55-58/data/058/058006/0932.htm.]

Penland, Shea; Westphal, K.A., Zganjar, Chris; Connor, Paul; Tao, Qiang; Mathies, Linda; Nord, Beth; and Gunn, Robert, 1997, Beneficial Use Monitoring Program 1996 annual report_-Part 4 - Results of monitoring the beneficial use of dredged material at MRGO, Breton Island - Base year 1985 through fiscal year 1996: Baton Rouge, La., U.S. Army Corps of Engineers, Louisiana State University, 18 p. [Also available at http://www.mvn.usace.army.mil/Portals/56/docs/OPS/ BUD/1996MRGOBretonIslandBUMP.pdf.]

Ritchie, William, and Penland, Shea, 1988, Rapid dune changes associated with overwash processes on the deltaic coast of South Louisiana: Marine Geology, v. 81, no. 1, p. 97-122.

[Also available at http://dx.doi.org/10.1016/0025-3227(88)90020-5.]

Ruple, D.L., 1984, Occurrence of larval fishes in the surf zone of a northern Gulf of Mexico barrier island: Estuarine, Coastal and Shelf Science, v. 18, no. 2, p. 191-208. [Also available at http://dx.doi.org/10.1016/0272-7714(84)90106-9.]

Sallenger, A.H., Jr., 2000, Storm impact scale for barrier islands: Journal of Coastal Research, v. 16, no. 3, p. 890-895. [Also available at http://coastal.er.usgs.gov/hurricanes/publications/jcr.pdf.]

Sallenger, A.H., Jr., Krabill, W.B., Swift, R.N., Brock, J., List, J., Hansen, Mark, Holman, R.A., Manizade, S., Sontag, J., Meredith, A., Morgan, K., Yunkel, J.K., Frederick, E.B., and Stockdon, H., 2003, Evaluation of airborne scanning lidar for coastal change applications: Journal of Coastal Research, v. 19, no. 1, p. 125-133. [Also available at http://www.jstor.org/stable/4299152.]

Sallenger, A.H., Stockdon, H.F., Fauver, Laura; Hansen, Mark; Thompson, David; Wright, C.W., and Lillycrop, Jeff, 2006, Hurricanes 2004-An overview of their characteristics and coastal change: Estuaries and Coasts, v. 29, no. 6, p. 880-888.

[Also available at http://dx.doi.org/10.1007/BF02798647.]

Sallenger, A.H., Jr., Wright, C.W., Howd, Peter; Doran, Kara; and Guy, Kristy, 2009, Extreme coastal changes on the Chandeleur Islands, Louisiana, during and after Hurricane Katrina, chap. B of Lavoie, Dawn, ed., Sand resources, regional geology, and coastal processes of the Chandeleur Islands coastal system-an evaluation of the Breton National Wildlife Refuge: U.S. Geological Survey Scientific Investigations Report 2009-5252, p. 27-36. [Also available at http://pubs.usgs.gov/sir/2009/5252/.]

Schott, Timothy; Landsea, Chris; Hafele, Gene; Lorens, Jeffrey; Taylor, Arthur; Thurm, Harvey; Ward, Bill; Willis, Mark; and Zaleski, Walt, 2012, The Saffir-Simpson hurricane wind scale: National Oceanic and Atmospheric Administration, National Hurricane Center, 4 p.

[Also available at http://www.nhc.noaa.gov/pdf/sshws.pdf.]

Shalowitz, A.L., 1964, Shore and sea boundaries-Interpretation and use of Coast and Geodetic Survey data: Washington, D.C., U.S. Department of Commerce, Publication 10-1, v. 2. 
Shoreline, 2015, National Oceanic and Atmospheric Administration, Shoreline information and download web page, accessed August 20, 2015, at http://shoreline.noaa.gov/data/datasheets/t-sheets.html.

Stewart, S.R., 2004, Tropical cyclone report-Hurricane Ivan, 2-24 September, 2004: Miami, Fla., National Hurricane Center, $44 \mathrm{p}$.

[Also available at http://www.nhc.noaa.gov/data/tcr/AL092004_Ivan.pdf.]

Stockdon, H.F., Sallenger, A.H., Jr., List, J.H., and Holman, R.A., 2002, Estimation of shoreline position and change using airborne topographic lidar data: Journal of Coastal Research, v. 18, no. 3, p. 502-513. [Also available at http://www.jstor.org/stable/4299097.]

Stockdon, H.F., Sallenger, A.H., Holman, R.A., and Howd, P.A., 2007, A simple model for the spatiallyvariable coastal response to hurricanes: Marine Geology, v. 238, no. 1-4, p. 1-20.

[Also available at http://dx.doi.org/10.1016/j.margeo.2006.11.004.]

Stone, G.W., and Stapor, F.W., Jr., 1996, A nearshore sediment transport model for the northeast Gulf of Mexico coast, U.S.A.: Journal of Coastal Research, v. 12, no. 3, p. 786-793.

[Also available at http://journals.fcla.edu/jcr/article/view/80238.]

Stone, G.W., Williams, S.J., and Burruss, A.E., 1997, Louisiana's barrier islands-An evaluation of their geological evolution, morphodynamics and rapid deterioration: Journal of Coastal Research, v. 13, no. 3, p. 591-592. [Also available at http://journals.fcla.edu/jcr/article/view/80173.]

Stone, G.W., and McBride, R.A., 1998, Louisiana barrier islands and their importance in wetland protection-Forecasting shoreline change and subsequent response of wave climate: Journal of Coastal Research, v. 14, no. 3, p. 900-915. [Also available at http://journals.fcla.edu/jcr/article/view/80676.]

Stone, G.W., Liu, Baozhu, Pepper, D.A., and Wang, Ping, 2004, The importance of extratropical and tropical cyclones on the short term evolution of barrier islands along the northern Gulf of Mexico, USA: Marine Geology, v. 210, no. 1-4, p. 63-78.

[Also available at http://dx.doi.org/10.1016/j.margeo.2004.05.021.]

Stone, G.W., Zhang, Xiongping; and Sheremet, Alexandru, 2005, The role of barrier islands, muddy shelf and reefs in mitigating the wave field along coastal Louisiana: Journal of Coastal Research, Special Issue No. 44, p. 40-55. [Also available at http://www.jstor.org/stable/25737048.]

Terrano, J.F., Flocks, J.G., and Smith, K.E.L., 2015, A GIS compilation of vector shorelines and associated shoreline change data for Breton Island, Louisiana-1869-2014. U.S. Geological Survey data release, accessed December 20, 2015, at http://dx.doi.org/10.5066/F7XS5SGM.

Terrano, J.F., Flocks, J.G., and Smith, K.E.L., 2016, Topobathymetric Lidar Survey of Breton and Gosier Islands, Louisiana, January 16 and 18, 2014. U.S. Geological Survey data release, accessed March 20, 2016, at http://dx.doi.org/10.5066/F70G3H6G.

Thieler, E.R., and Danforth, W.W., 1994, Historical shoreline mapping (I) —Improving techniques and reducing positioning errors: Journal of Coastal Research, v. 10, no. 3, p. 549-563.

[Also available at http://journals.fcla.edu/jcr/article/view/79405.]

Thieler, E.R., Himmelstoss, E.A., Zichichi, J.L., and Ergul, Ayhan, 2009, Digital Shoreline Analysis System (DSAS) version 4.0-An ArcGIS extension for calculating shoreline change: U.S. Geological Survey Open-File Report 2008-1278.

[Also available at http://woodshole.er.usgs.gov/project-pages/DSAS/version4/.] 
Thomson, Gordon; Miner, Michael; Wycklendt, Andrew; Rees, Michelle; Swigler, David, 2010. MRGO Ecosystem Restoration Feasibility Study_Chandeleur and Breton Islands: Boca Raton, Fla., Coastal Planning \& Engineering, Inc., 96 p. [Also available at https:/www.doi.gov/sites/doi.gov/files/ migrated/deepwaterhorizon/adminrecord/upload/MRGO-Ecosystem-Restoration-Feasibility-StudyChandeleur-And-Breton-Islands-April-2010.pdf.]

Van Heerden, I.L., and DeRouen, Karl, Jr., 1997, Implementing a barrier island and barrier shoreline restoration program - The state of Louisiana's perspective: Journal of Coastal Research, v. 13, no. 3, p. 679-685. [Also available at http://journals.fcla.edu/jcr/article/view/80180.]

Westphal, K., Penland, S., Weathers, D., and Paulsell, R., 2009, Louisiana barrier island comprehensive monitoring program (BICM) - Volume 1: Barrier Shoreline Post-Storm Assessment : Prepared for the Louisiana Department of Natural Resources, Coastal Restoration Division by the University of New Orleans, Pontchartrain Institute for Environmental Sciences, New Orleans, Louisiana.

[Also available at http://lacoast.gov/reports/project/3890914 1.pdf]

Williams, S.J., Penland, Shea, and Sallenger, A.H., Jr., 1992, Louisiana's hurricane history, appendix A of Atlas of shoreline changes in Louisiana from 1853 to 1989-Louisiana Barrier Island Erosion Study: Reston, Va., U.S. Geological Survey Miscellaneous Investigations Series I-2150-A, p. 98-99. [Also available at https://pubs.er.usgs.gov/publication/i2150A.]

Williams, S.J., Stone, G.W., and Burruss, A.E., 1997, A perspective on the Louisiana wetland loss and coastal erosion problem: Journal of Coastal Research, v. 13, no. 3, p. 593-594. [Also available at http://journals.fcla.edu/jcr/article/view/80174.]

Withers, Kim, 2002, Shorebird use of coastal wetland and barrier island habitat in the Gulf of Mexico: The Scientific World Journal, v. 2, p. 514-536.

[Also available at http://dx.doi.org/10.1100/tsw.2002.112.]

Wright, L.D., Swaye, F.J., and Coleman, J.M., 1970, Effects of Hurricane Camille on the landscape of the Breton-Chandeleur Island chain and the eastern portion of the Lower Mississippi Delta: Baton Rouge, La., Louisiana State University, Baton Rouge Coastal Studies Institute, Technical Report 76. [Also available at http://www.dtic.mil/dtic/tr/fulltext/u2/709427.pdf.]

XTools, LLC, 2016, XTools Pro (ver. 11.1328) [Computer Software]: XTools Pro extension for ArcGIS software. Web page, accessed December 10, 2015, at https:/xtools.pro/en/overview/.

Yamazaki, Gordon, and Penland, Shea, 2001, Recent hurricanes producing significant basin damage, in Penland, Shea, Beall, Andrew, and Kindinger, Jack, eds., Environmental atlas of the Lake Pontchartrain Basin: New Orleans, La., Lake Pontchartrain Basin Foundation, U.S. Geological Survey Open-File Report 02-206, p. 36-37.

Yates, Xan, Nayegandhi, Amar, Brock, J.C., Sallenger, A.H., Klipp, E.S., and Wright, C.W., 2009, ATM coastal topography-Louisiana, 2001: UTM Zone 16 (part 2 of 2): U.S. Geological Survey Data Series 465. [Also available at http://pubs.usgs.gov/ds/465/]. 
